\title{
Coastal zone of the world's great lakes as a target field for interdisciplinary research and ecosystem monitoring: Lake Baikal (East Siberia)
}

IIMNOLOGY ERESHWATER

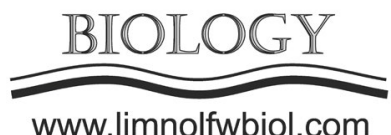

\section{Timoshkin O.A.}

Limnological Institute, Siberian Branch of the Russian Academy of Sciences, Ulan-Batorskaya Str., 3, Irkutsk, 664033, Russia

\begin{abstract}
Limnological data on the coastal zone of the world's greatest lakes are scanty in contrast to the deep-water research that is actually the main reason for a delayed response of the researchers' and public community to evident anthropogenic changes the lake ecosystems are experiencing worldwide. The present study reports on the interdisciplinary investigations in the coastal zone of Lake Baikal during 2000-2018 and gives a brief description of the splash zone as a principal part of the lake ecosystem poorly known in other lakes of the Planet so far. Recent surveys of Lake Baikal showed a key role of the coastal zone research for the fundamental limnology and efficient monitoring of the lacustrine ecosystems. The splash zone of Baikal is briefly described due to its peculiarity. Principal reasons of significance of lake coastal zone research such as: maximal biodiversity of lacustrine ecosystems, high macrobenthos productivity in Baikal, intensive biogeochemical processes in rift and karst lakes and their reasoning are described. This is the zone that first of all colonized by invasive species and where the obvious cyclicity in plankton-benthos relationships is clearly expressed. Early warning signs for the ecological disturbance, such as blooms and wash-ups of native and/or alien algae, degradation of pelagic and benthic communities, bioaccumulation of pollutants (including organochlorine compounds) by hydrobionts, etc. are manifested in the coastal zone. A short report of the current ecological crisis in the coastal zone by 2018 is presented. The uniqueness of Lake Baikal makes the ongoing eutrophication different from all other Palearctic lakes. Therefore, the hydrochemical indicators of the water column of great lakes do not match the commonly accepted principal eutrophication criteria pool. Biological indication approach appears most appropriate for the analysis of the initial eutrophication stages. The author points out real and potential sources of excessive biogenic element supply into the lake ecosystem such as, sewage contamination of the estuarine parts of Baikal tributaries by the coastal settlements and vessels, pollution of the ground and interstitial waters of the beaches, input of biogenic elements as a result of mass mortality of sponges and other hydrobionts, secondary contamination by decaying algal wash-ups, intensive nutrient influx after numerous forest fires on the lake coasts and aerosol contamination. All these factors provide new opportunities to evaluate the initial eutrophication stages either on Baikal or in any other of the giant lakes. Special emphasis is given to an inadequate governmental lake monitoring systems focusing on the pelagial zone without taking into consideration the coastal (splash zone included) biological communities. Our landscape-ecological method served a basis for elaborating approaches for complex monitoring of Baikal coastal zone recommended as a part of the Federal Baikal Ecosystem Monitoring.
\end{abstract}

Keywords: coastal and splash zones, community degradation, Spirogyra, blue-greens, algal blooms, plankton and benthos interrelations, invasive species, Lubomirskiidae mortality, ecocrisis, POP bioaccumulation, monitoring, Baikal

\section{Introduction: what is the problem?}

Brief analysis of the world limnological literature evidences, that pelagic zone of the great lakes seems to be much more precisely and regularly investigated as compared to their coastal zone (splash zone includ- ing). Most of the governmental monitoring schemes exclusively concentrated on the hydrochemical, hydrobiological etc. parameters and their dynamics in the pelagic zone (Zohary and Gasith, 2014; Timoshkin et al., 2015; 2018). If we will compare the data on the multiyear dynamics of the plankton and macrozoobenthos communities in the great lakes of the globe at the 
species level, it became evident, that available information on the successions of the benthonic communities, as distinct of planktonic ones, is very limited, scarce or even lacking (ILEC..., 1999-2018; Kravtsova et al., 2009). From this viewpoint Lake Baikal offers exemplary illustration. Indeed, the current ecological condition of Baikal ecosystem is interpreted in a diametrically opposed manner. Scientists, investigating the pelagic zone, evidence on the main hydrochemical parameters, remaining more or less stable during last 50 years of investigations (Khodzher et al., 2017); POP concentration in zooplankton and fish are quite compatible with that of the fishes from high mountain Alpine lakes of Europe (Gorshkov et al., 2017), changes in zooplankton during last 60 years are correlated with global warming $^{1}$ (Hamton et al., 2008; Moore et al., 2009; Izmesteyeva et al., 2016). Alternatively, limnologists, dialing with coastal zone, warn of profound changes in benthonic communities, related to anthropogenic pressure; high POP concentrations in some benthonic algae and invertebrates, hydrochemical and microbiological pollution of stretches of the rivers within the settlements and the near-shore zone, etc. Moreover, according to their viewpoint, some of these ecological changes might already be irreversible (for short characteristics of the ecological crisis in the coastal zone and main References, see below).

In the common sense, a formerly polluted (eutrophied, for example) lacustrine ecosystem is usually considered "enough recovered", if its hydrochemical parameters as well as the qualitative and quantitative characteristics of the plankton became close to initial ones. Such conclusions, based only on offshore sampling, are often false. Normal hydrochemical parameters in the giant or - "hydrochemically recovered" after eutrophication smaller lakes may "coexist" with deeply depressed and modified benthonic communities.

"Interestingly, governmental monitoring in many countries also focuses on the offshore pelagic zone while mostly ignoring the nearshore zone. For example, a deficit of coastal monitoring in the Laurentian Great Lakes caused the USA and Canada, in their latest revision of the Great Lakes Water Quality Agreement (2012), to call for a "Nearshore Framework" that includes enhanced study and monitoring of coastal environments throughout the Great Lakes" (cited from Timoshkin et al., 2016).

The aim of this paper is to summarize the main results of the interdisciplinary investigations of Baikal coastal zone (2000-2018) and to show their importance in terms of both: for theoretical limnology and for the establishment of the optimal schemes of the great lakes monitoring. I just wish to draw the attention of the scientists to this extraordinarily important field of limnology.

The investigation methods were published earlier (Timoshkin et al., 2011; 2012a; 2012b; Kulikova et al., 2012; Tomberg et al., 2012). All photos are taken by the author (if not indicated differently); some of

1 Strictly speaking, correlation does not automatically mean, that two (or more) correlating processes have cause-andeffect relationships. them are taken from the scientific archives of the projects, supervised by the author.

\section{What is the coastal zone in the lakes?}

Similarly to marine and oceanic ecosystems, the coastal zone of the lakes includes shallow water, splash zone and the area between the upper border of the splash zone and the slope foot (or - constructions like parapets, etc.). Due to the specific hydrological conditions and Irkutsk hydroelectric power station activity, the term "splash zone" of Lake Baikal should be considered separately.
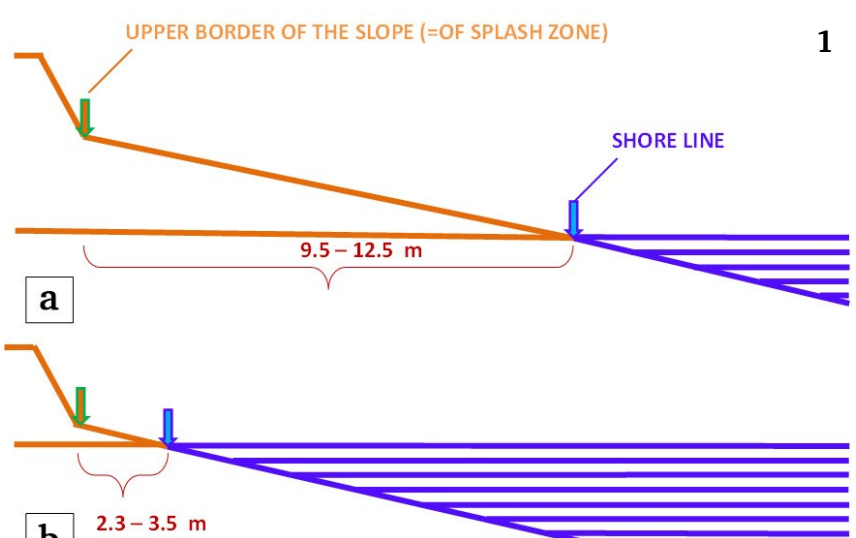

b $2.3-3.5 \mathrm{~m}$

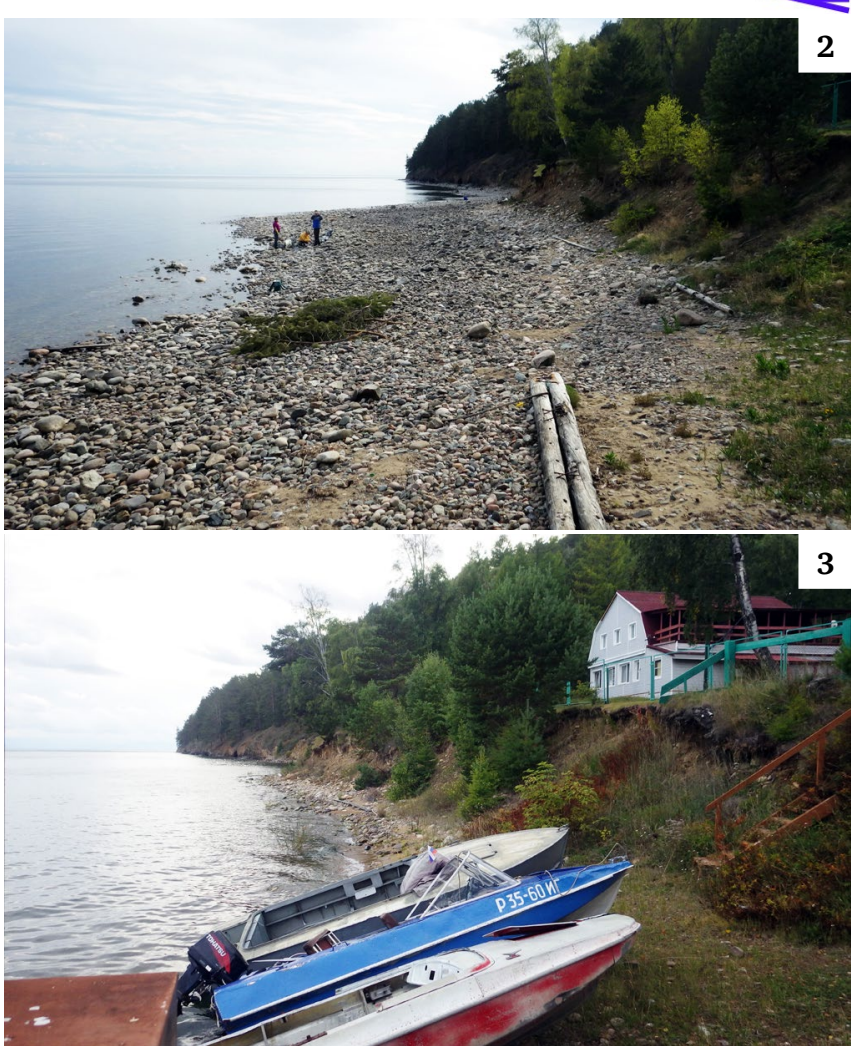

Fig. 1. Intra-annual fluctuations of the water level (the upper border of the splash zone) along the standard transect, opposite of the field station of Limnological Institute SD RAS, Bol'shye Koty Bay; western coast of South Baikal in 20112018. a - May-June. b - September (after Timoshkin et al., 2011; modified). 2, 3 - intra-annual fluctuation of the water level, the same area and the standard photograph position: low water level, May 25, 2016; typical for the spring season (2); high water level, September 4, 2018; typical for the autumn season (3). 


\subsection{Baikal splash zone: definition; importance for interdisciplinary research and moni- toring}

The term "splash zone" is commonly used by marine biologists in intertidal zonation, denoting a part of the littoral zone subjected to water splashes. Evidently, a similar zone with a variety of environmental gradients, defined by abiotic factors also exists in all the great lakes. Splash zone of the most Eurasian lakes remains a white spot for limnologists.

E.B. Karabanov (1990) was the first, who introduced the term "splash zone" into limnology of Lake Baikal. It was characterized as analog of the supralittoral zone in marine ecosystems, which occupies the coastal area between the shore line and $2 \mathrm{~m}$ above the water level. However, after our interdisciplinary investigations of Baikal splash zone (Timoshkin et al., 2011; 2012a-c), the definition was significantly changed. Baikal splash zone is a mobile zone, the borders of which are constantly migrating throughout the year as a result of the spring-summer rise of the lake level. Its upper border migrates 10-14 m (western shore, e.g., Bolshye Koty Bay) or up to 15-20 m (eastern shore, bays) landward (Fig. 1), and in winter-spring period it moves significantly backward. The Lake water level varies within ca. $1 \mathrm{~m}$.

As the intermediate zone, the splash zone represents a combination of abiotic and biotic factors, typical for both - terrestrial and lacustrine ecosystems. "Terrestrial ecologists" consider the splash zone as a part of the limnic ecosystem, their standard transects usually ended at the lake's slope. Vice versa, the standard limnological transects usually begin at the shore line of the lakes. The splash zone remained "owner-less, or - abandoned". This is the main reason why our knowledge on the limnic splash zones has been so poor. Meanwhile, Baikal splash zone has been found out to be rich in feeding resources: high concentrations of detritus and domestic waste providing a favourable biotope for specific communities and affecting hydrochemistry and microbiology of interstitial and coastal waters. Four invertebrate faunistic complexes of different origin were described in this zone: Palearctic, cosmopolitan and other species (immigrants from Eurasian or Siberian water bodies) (1); common or endemic Baikal hydrobionts (2); as well as soil infauna migrants, such as earthworms (3) and representatives of terrestrial biocenoses - beetles, spiders, etc. (4) (Timoshkin et al., 2011; 2012a-c). Most of the endemic "hydrobionts" dwelling the splash zone of Baikal were found to be evolutionary young and can be considered as a perfect model objects for interdisciplinary investigations of the initial stages of the endemic speciation. Recent observations showed that this zone is subject to most heavy anthropogenic load: its grounds serve a special buffer filtering household waters discharged from the neighboring settlements; maximal concentration of domestic waste is registered in the splash zone. Hence, the anthropogenic load on the lake can be easily recorded

2 Literally, the permanent residents of this zone are already not hydrobionts, but - "splash zone inhabitants".

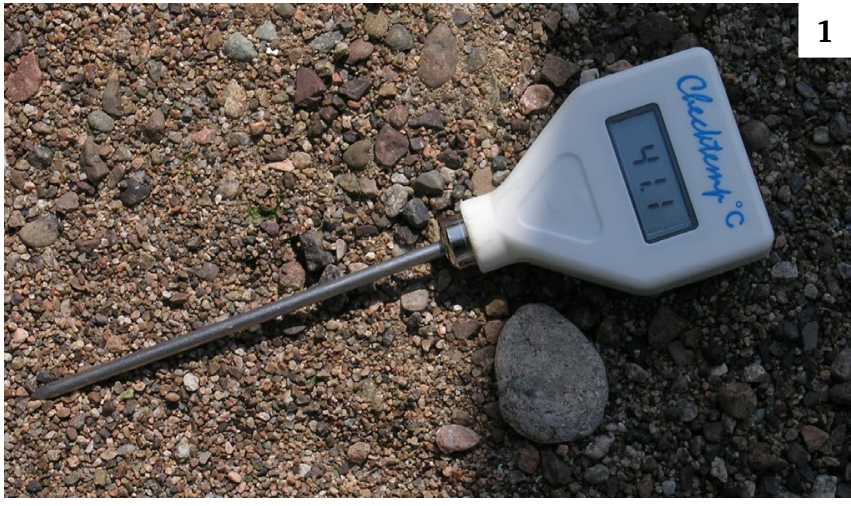

June 23, 2010; Bol. Koty, Sennaya Bay; 16:30 2 (sunny day, no clouds, shade air temperature $30 \mathrm{o}$ c)

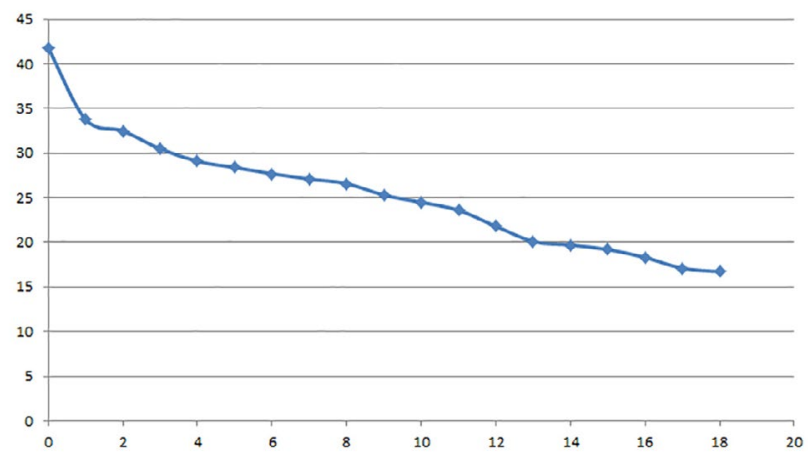

Fig. 2. Example of the surface temperature $\left(\mathrm{C}^{\circ}\right.$, Checktemp Co.) (1) and its variation ( $\mathrm{C}^{\circ}, \mathrm{Y}$ axis) within the soil profile (2) (cm; X axis) in the splash zone. Measurements taken ca. $1 \mathrm{~m}$ above the shoreline.

in the splash zone, a sensitive "indicator" of the changes in Baikal ecosystem. While the animal diversity in splash zone is comparatively poor and the macrozoobenthos communities, as a rule, are "monodominant", the simple monitoring scheme has been elaborated and proposed (ob. cit.). Monitoring of the great lakes splash zone must be viewed as an indispensable integral part of the effective monitoring scheme of their ecosystems (Timoshkin et al., 2011; 2012a).

\section{Why coastal zone is so important for interdisciplinary investigations and ecosystem monitoring?}

\subsection{Zone of the maximum biodiversity}

The maximum abundance and number of species in 14 largest lakes of the globe dwell the coastal (shallow water) zone, even if it occupies comparatively small area of the lake (Vadeboncoeur et al., 2011). The same is true for many ancient lakes (Kostoski et al., 2010; von Rintelen et al., 2012), including Lake Baikal (Index of animal..., 2001-2011; Timoshkin, 2001; Timoshkin et al., 2004; Semernoy, 2007): their highest biodiversity concentrated in the coastal zone. The greatest species diversity in Lake Baikal occurs on the substrate in shallow waters ranging in depth from 1 to

3 Means, that 1-2 species of turbellarians, oligochaetes, gammarids, etc. are dominating in the communities. 
$50 \mathrm{~m}$. Zohary and Gasith (2014) state, that most fish and macro-invertebrates of Lake Kinneret use littoral habitats for at least part of their life cycle. Many hydrobionts use littoral resources (substrate for attachment, refuge, food) for reproduction and growth.

\subsection{Zone of high benthos productivity}

From the common viewpoint, Baikal water has low mineralization and potentially cannot support the high productivity rates of benthonic communities. Nonetheless, as stated earlier (Kravtsova et al., 2009; Timoshkin et al., 2009), the biomass and number of macrozoobenthos of the stony bottom of Lake Baikal in 2000-2003 was high enough: $59 \pm 5.1 \mathrm{~g} / \mathrm{m}^{2}$ and $11 \pm 0.7$ thousand specimens $/ \mathrm{m}^{2}$ respectively ${ }^{4}$. These parameters are substantially higher than that in other lakes of the globe, for example, Khubsugul $\left(4.8 \mathrm{~g} / \mathrm{m}^{2}\right)$, Issyk-Kul' (5-7 g/m²), etc. (Kravtsova et al., 2009). As distinct, the productivity of marine zoobenthos may be several times higher and runs, for example, in Caspian Sea, up to $240.7 \mathrm{~g} / \mathrm{m}^{2}$ (Guseinov, 2005). So, from this viewpoint, Lake Baikal occupies intermediate position between ordinary Palearctic lakes and marine ecosystems. Which factors may provide possibility for abundant zoobenthos development in Baikal?

\subsection{Zone of intensive biogeochemical processes}

Coastal zone (and - in particular - the near shore and splash subzones) is the area of maximum concentration of the authochtonous and allochtonous organic matter, strongest intermixing processes (wave activity) and rather contrast environmental parameters. In combination with decomposition of wash ups $^{5}$, high surface and inside the sandy bottom temperatures of the splash zone, vital activity of algal belts, they may significantly intensify the rates of biogeochemical processes, rock hydrolysis, and, indirectly the benthos productivity. Both - experimental and in situ observations support these conclusions. During the calm sunny day the surface sandy bottom temperature in the splash zone may exceed $40{ }^{\circ} \mathrm{C}$; at $5 \mathrm{~cm}$ below bottom surface it varies within $27-30{ }^{\circ} \mathrm{C}$ (Fig. 2; original data). As evidenced by series of papers, summarizing results of our interdisciplinary research (2008-2018), an important role in the biogeochemical cycles of the coastal zone belongs to attached organisms - lichens, macrophytes and sponges. First, in the process of the vital activity they may significantly influence and change the hydrochemical parameters of the near shore and near the bottom water layers of the coastal zone. For example, the main hydro-

4 These numbers are compatible with earlier data on macrozoobenthos productivity (Kozhov, 1963).

5 First classification of Baikal wash-ups of different origin and the data on their seasonal and annual dynamics; their influence on the hydrochemical regime and the elemental composition of the interstitial waters of the splash and near shore zones can be found in Kulikova et al., 2012; Timoshkin et al., 2011; 2012a-c; Tomberg et al., 2012. chemical parameters, measured in June-August within the near shore zone, occupied by typical filamentous alga Ulothrix zonata, may be as high as $\mathrm{pH}$ 9-9.5; dissolved oxygen - up to $150 \%$ of the saturation limits (Volkova et al., 2012; original data). The same parameters, measured in the mesocosm experiments with $U$. zonata, show much higher ranges (day time): $\mathrm{pH} 11.6$; $\mathrm{O}_{2}$ saturation limits up to $260 \%$ (ob. cit.). Kulikova et al. (2008) found that the underwater lichens of Verrucaria genus cover $60-70 \%$ of the rock debris and widely distributed along the west coast of South Baikal (in particular - Berezovy test-site, Bol'shye Koty areas) at 1-14 $\mathrm{m}$ depth, with maximum abundance at 1-3.5 $\mathrm{m}$. Depending on the rock type, the projective area on the bottom of Baikalospongia encrusting sponges, dwelling at the same depth range, vary within 14-100\% (Kulikova et al., 2009a; see below).

Second, they are able to synthesize and extract a wide spectrum of macro- and microelements, organic compounds (including environmentally aggressive organic acids), which literally destroy the minerals of the stony bottom and perform significant vital element contribution to the ecosystem. At least three indirect data sets support this conclusion: 1) significant abundance and huge biomass of sponges ${ }^{6}$ simply cannot be determined by nutrients (especially - of silica, for example) taken from the water column only; 2) the same is true with regard to the elemental composition of the dominant groups of hydrobionts (Kulikova et al., 2007; 2008a; 2008b; 2009b; 2011; 2013; 2017; 2018); 3) selectiveness of biofilms, algae and invertebrates to the petrographic composition of the rocks on stony bottoms of the coastal zone (Timoshkin, 2001-2011; Suturin et al., 2005; Timoshkin et al., 2005; 2009; Parfenova et al., 2008).

In situ experiments with the artificial sterile plates made of 3 dominant rock types, distributed on the stony bottom of the Berezovy test-site and exposed at 3-10 m depth for 1-18 months on the Lake's bottom, evidences, that microorganisms, microphytobenthos and meiozoobenthos organisms strictly prefer the marble and granitoid substrates rather than amphibolite plates (ob. cit). Similar results obtained with encrusting sponge and gastropod mollusks investigations. Analysis of underwater rocky bottom photographs and the petrographic composition of the rocks with attached invertebrates evidences, that both invertebrate groups demonstrate selectiveness of the rock types to inhabit. They both prefer to dwell the destroyed granitoids rather than amphibolites. Rather high density of gastropods was detected on granitoids with carbonate and mica rockstreaks, while sponges prefer to inhabit the granitoids with microcline and garnet rockstreaks (Timoshkin et al., 2003). Therefore, the biodiversity and bioproduction on the stony littoral depend on the diversity of the petrographic composition of rocks and their geochemical properties. Evidently, the geochem-

6 Sponges - the most abundant macrozoobenthos group in the stony areas of the coastal zone of Lake Baikal. Their wet biomass may reach up to $3 \mathrm{~kg} / \mathrm{m}^{2}$ for encrusting and up to $1.5 \mathrm{~kg} / \mathrm{m}^{2}$ - for Lubomirskia baikalensis (Kozhov et al., 1969; Kaplina, 1970). 
ical factor shall be considered as one of the most important factors of the ecological segregation, endemic speciation and evolution in ancient lakes of carst and rift origin. Coastal erosion and mudflows contribute up to $1550000 \mathrm{~m}^{3}$ of the non-hydrolized stony material in the coastal zone annually (Agafonov, 2002). Therefore, the rocky bottom of the coastal zone shall be considered as an unlimited source of the vital elements and nutrients for Baikal ecosystem.

\subsection{Coastal zone is the most sensitive and first responding to contamination}

It became commonly accepted, that the coastal zone provides most accurate evidence of immediate ecosystem's response to the current anthropogenic changes.

First symptoms of phytoplankton and protozooplankton degradation of the great lakes can be traced in the coastal zone. They are especially illustrative opposite the tributaries and coastal settlements. Bondarenko and Logacheva (2016) described the degradation of coastal zone phytoplankton in 2000-2015. Algae of "Baikal complex", such as Aulacoseira baicalensis (K. Meyer) Sim., Cyclotella baicalensis Skv., Stephanodiscus meyeri Genkal et Popovsk., and spore-forming A. islandica were absent (or present in negligible amounts) ${ }^{7}$ and replaced by huge amounts (up to 7 million cells/ $\mathrm{dm}^{3}$ ) of small-cell Chlamydomonas species, as well as another indicators of organic pollution, euglenophytes (4-7 thousand cells $/ \mathrm{dm}^{3}$ ). These algae did not occur in plankton earlier (1975 to $\left.1990^{\text {th }}\right)$, their insignificant amounts appeared in beginning of XX century. The authors believe, that these structural changes in phytoplankton and dominance of the small-cell species shall be considered as clear evidences of the eutrophication of the Lake Baikal shallow areas.

\subsection{Benthos of coastal zone - among the first responders to anthropogenic contamination}

Several negative ecological phenomena have been detected in Baikal coastal zone within last 5-7 years.

1. Significant changes in the macrophyte belt composition, development and stratification were described (Kravtsova et al., 2012; 2014; Timoshkin et al., 2015; 2016; 2018; Timoshkin, 2018; Volkova et al., 2018). In 2013-2018, a mass blooms of non-typical for Baikal algae - Spirogyra spp. were detected with maximum biomass in autumn in the shallow water zone throughout much of the lake ${ }^{8}$ : Baikalsk, Slyudyanka, Kultuk towns; along the Old Baikalian Rail Way; List-

7 At the same time, these species vegetated in open areas of Lake Baikal.

8 It is easier to indicate areas where the alga was not found: Bol'shoi Ushkani Island, most of the coastline of Ol'khon Isl. (except for Perevoznaya Bay and a coast opposite Khuzhir), and the northwestern coast from Elokhin Cape to Maloe More Strait (with several exceptions of patchy distribution in areas of recreation activity). vyanichnoe, Obuteikha, Bolshye Koty, Peschanaya, Babushka, Aya Bays; Goloustnoe settlement (South Baikal); some areas of Maloe more Strait; Maksimikha Bay (Middle Baikal); Nizhneangarsk, Severobaikalsk towns; Senogda, Frolikha, Ayaya, Onokochanskaya and Boguchanskaya Bays (North Baikal). Also in 2014-2017, the mass development of Spirogyra was noted on Ol'khon Island at two localities (i.e., the ferry harbor in Perevoznaya Bay and Shamanka Bay opposite the town of Khuzhir on Ol'khon Island). By 2015, mass growth of Spirogyra was reported at several new localities along the west coast of South Baikal (Emelyanikha, Sennaya Bays and a coast opposite Polovinnyi Cape) as well as Maloe More Strait (i.e., coastal zone off Sakhyurte Settlement and Kargante Bay). From 2016 its remarkable autumn proliferation was detected in Aya Bay (one year after the new hotel, ca. $300 \mathrm{~m}$ away of the shore line was opened there), and in majority of the north-western shallows from Senogda Bay to Elokhin Cape. In summary, Spirogyra spp. developed massively and even dominated the benthic macroalgal community along much of the eastern coast, and in many places along the western coast of Lake Baikal. Interestingly, the maximum development of spirogyra - a comparatively thermophilic algae (optimal temperature for growth is ca. $20^{\circ} \mathrm{C}$ ), was always detected during autumn (September-October) with water temperatures ranging within $4-8^{\circ} \mathrm{C}$. At least, two sites investigated to date (i.e., Listvennichnyi Bay in South basin and TyyaSenogda coast in North basin) were characterized by year-round mass blooms of Spirogyra spp., which sometimes include other diatom and filamentous green algae species that previously were non-typical for open parts of Lake Baikal (such as Oedogonium spp.; or Fragillaria spp., which became extremely abundant in along to the west coast of North basin between Onokochanskaya and Senogda Bays; etc.). Starting from May-June 2016 mass development of Spirogyra has also been detected in the littoral opposite of Baikalsk City (at 3-7 $\mathrm{m}$ depths) and several wooden harbors (Khuzhir, Bolshye Koty settlements). It means, that the number of areas with the all-the-year round Spirogyra spp. mass development is gradually increasing. The same is true for the gradual horizontal distribution of the alga along the north-western coast - its area is increasing year by year, mostly at the depths of 0.5-2 $\mathrm{m}$.

Only one of ca. 12 Spirogyra morphotypes, found in the Lake and its tributaries, has been dominating in these areas of the lake's rocky littoral within 2013-2017. It has simple cell walls, 4 in "young" and one homogeneous chloroplast(s) - in "adult" cell; the filaments attached to the rocks by rhizoids (see Timoshkin et al., 2018 for additional description and color Figs). As a rule, this Spirogyra morphotype has patchy distribution in the coastal zone (especially sharply expressed along to the western and Olkhon Island coasts), the blooms are mostly concentrated opposite of the settlements and recreation centers (with poor or without any sewage water purification systems).

Results of 2016-2018 investigations evidence, that the Spirogyra morphotype 1 in significant masses develop from end of August till September-October 
and creates the new for Baikal, well distinguished algal belt at the depths range 1-10 $\mathrm{m}$ (with maximum abundance at 2-5 $\mathrm{m}$ ) along to the west coast from Senogda Bay to Elokhin Cape. It prefers to vegetate on the rocky bottom and avoid the cliffs. So far, the shallows of the later Cape is the most southern border of the belt distribution along to the west coast of the North Basin.

As shown by Timoshkin et al. (2018), neither global warming nor the cases of the comparatively low lake water level provide us any arguments to consider them as the key factors, influencing mass Spirogyra development in Baikal coastal zone. Moreover, the minor, but permanently entering the coastal zone nutrient additions from non-purified sewages provide possibility to overcame the depths of 20 (North Baikal) or even 30 (South Baikal - I.V. Khanaev, pers. comm.) meters! Evidently, Spirogyra morphotype 1 is very sensitive indicator of the human wastes and should be considered as a perfect indicator of the sewage water contamination in oligotrophic ecosystems such as Baikal.

2. Giant amounts of the coastal accumulated material, mostly consisting of algal detritus, have been detected in the north and south tops of the Lake and opposite of Maksimikha settlement (Barguzin Bay) (Fig. 3 ). Intensive development of macrophytes in Maksimikha Bay was due to Cladophora sp. (glomerata?) (ca. $50 \%$ of the total wet biomass), Characeae, Elodea and other higher water plants. The most pronounced Spirogyra blooming and wash ups were regularly found in the northern basin, along the western mouth of Tyya River and Zarechnoe-Senogda coasts (Severobaikalsk City vicinities) (Fig. 4). Wet biomass of this algal wash up opposite of Zarechnoe, in the autumn of 2013 reached up to $90 \mathrm{~kg} / \mathrm{m}^{2}$ (Timoshkin et al., 2015). All mentioned regions belong to the near-shore settlements or bays with poor or none waste purification systems and natural harbors for numerous vessels. The blooms shall be considered as the clear evidence of "indirect" eutrophication in many particular regions of the coastal zone. Evidently, the natural buffer and filtrating ability of Baikal's splash zone is limited. Abundant amount of nutrients can reach the interstitial and near-bottom water layers through the ground of the splash zone and cause the blooms. The distribution pattern of the fecal indicating bacteria (see below) strongly support this supposition and can be used as sewage benchmarks. Due to the huge size of the lake and permanent intense water-wind activity (mixing) high nutrient concentrations often cannot be detected by commonly accepted hydrochemical methods in the surface and near-bottom water layers.

3. Increase of the typical Baikalian macroalgae productivity in some areas of the shallow water zone. According to the world literature, it should be considered as early symptom of the eutrophication.

4. Mass development of the «saprophytic» (proliferating on sick sponges and died macrophytes, see below) (Figs 5, 9) and «free-living» blue-greens (Figs 6-8) in several areas of the Lake. Significant amount of the Oscillatoriales filaments have been first found by the author in the drudge benthonic samples, taken from
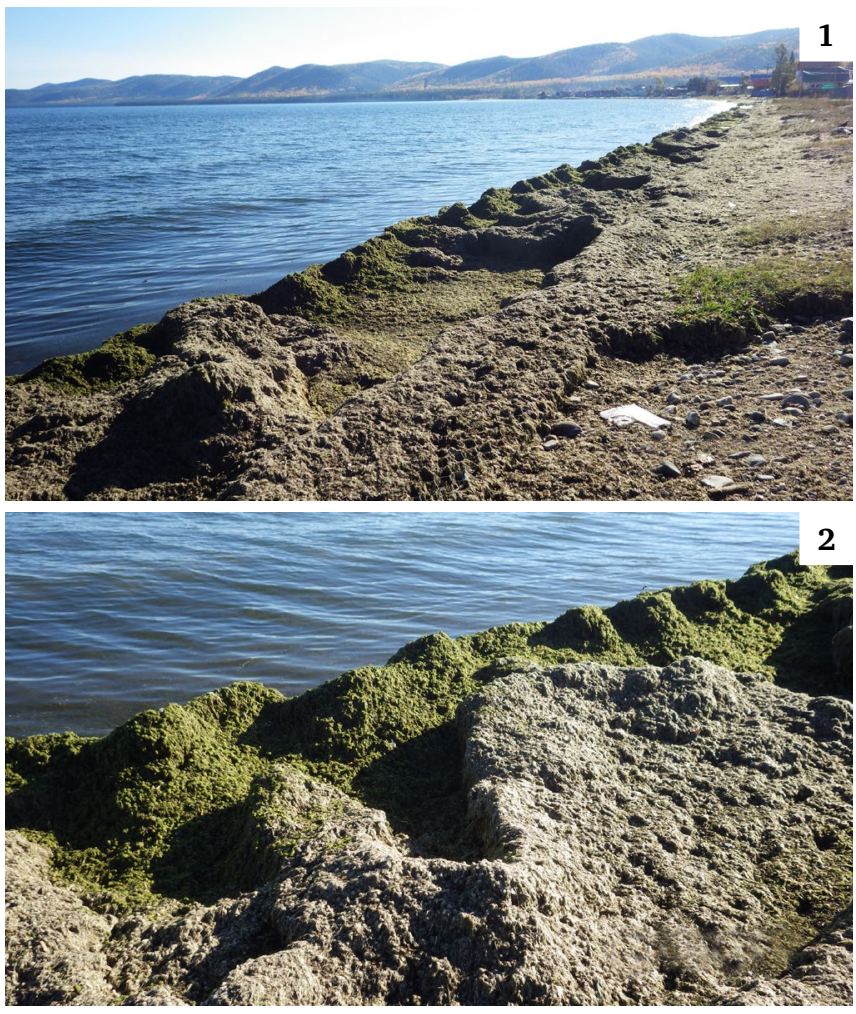

Fig. 3. Algal wash-ups opposite of Maximikha Settlement, Barguzin Bay, September 24, 2018.

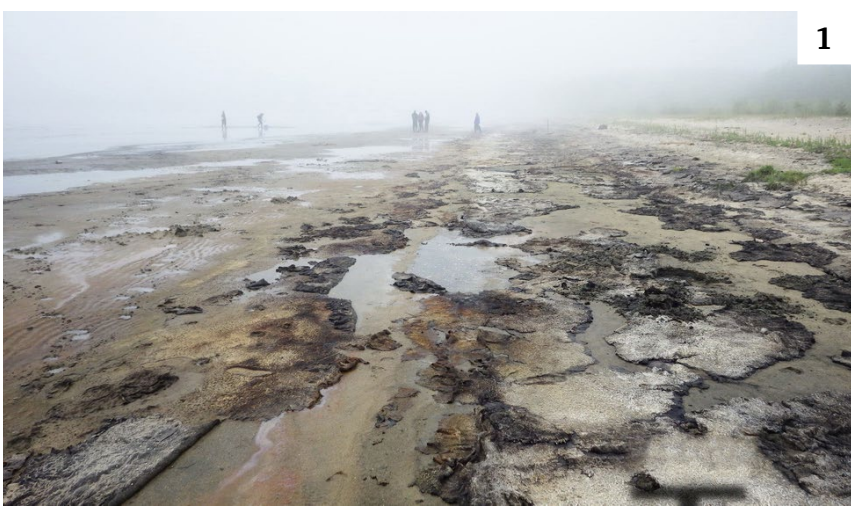

2

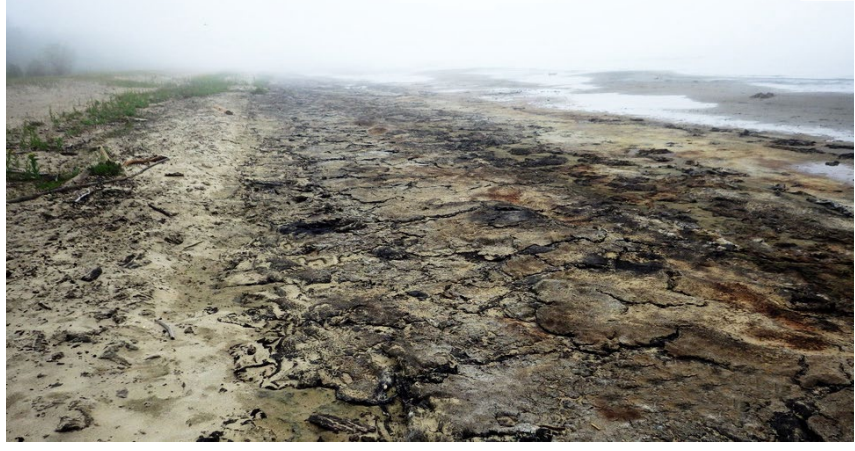

Fig. 4. Spirogyra wash-ups in Senogda Bay, north basin, June 12, 2018. 

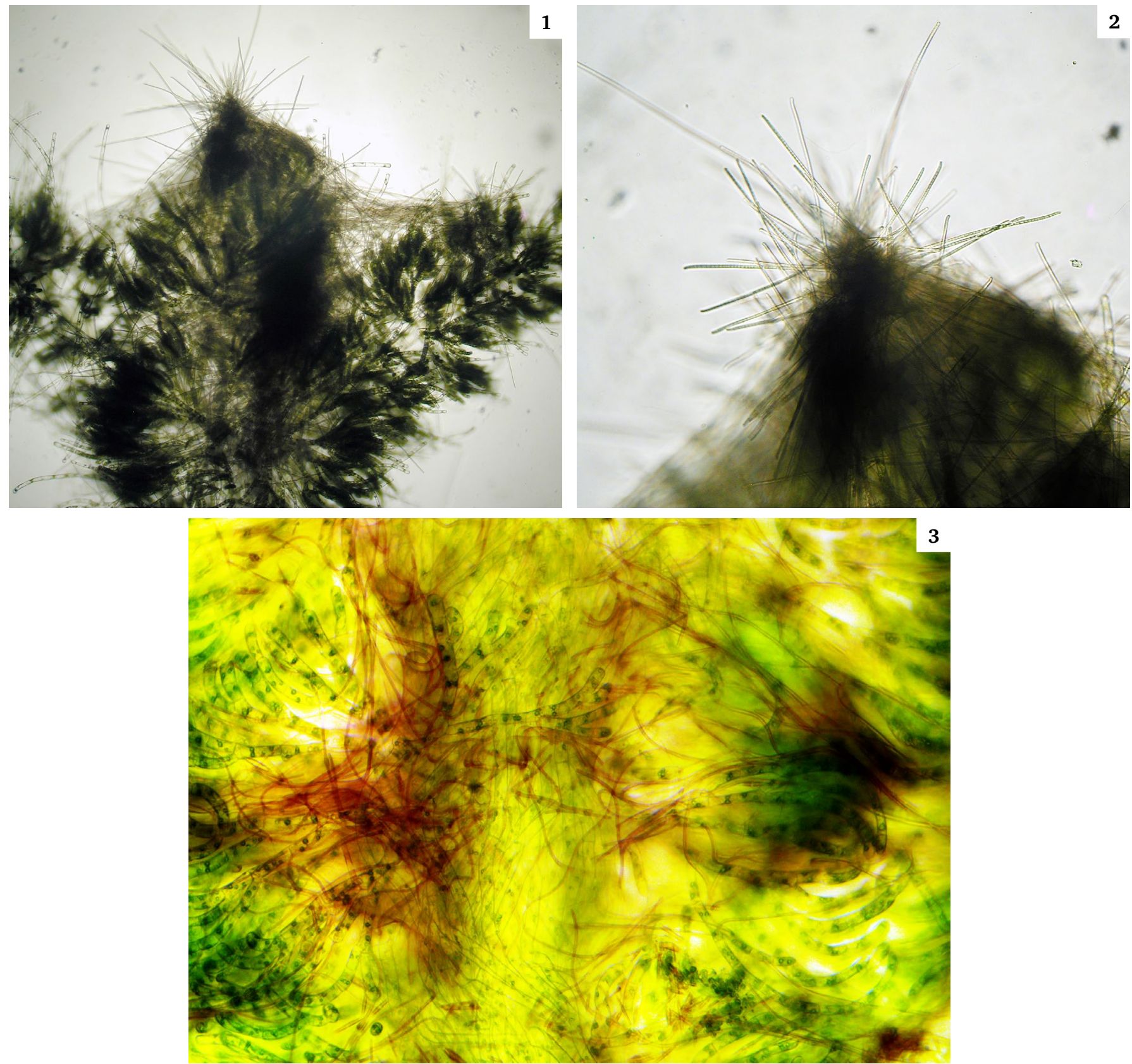

Fig. 5. Mass development of the "saprophytic" blue-greens (Oscillatoriales) on the dying thalli of Draparnaldioides spp. 1, 2 - opposite of the LIN SD RAS field station, Bolschye Koty Bay, August 1, 2011. Width of the algal branch on 1 - ca. 2.5 mm. 3 - The same, sample taken on July 25, 2018, the same area. Width of the branch of Draparnaldioides - ca. $1.1 \mathrm{~mm}$.

10-15 m depth, southern of Peschanaya Bay (South Baikal), in summer of 2013 and 2014. In 2015-2016 their mass blooming found as well in the shallows of Bolshye Koty, Barguzin bays, etc. (Phormidium, Oscillatoria, Tolypothrix spp. and others). Most unusual is the mass penetration of the Tolypothrix, Oscillatoria and other cyanoprocaryote spp. into the first algal belt, usually created by green filamentous alga Ulothrix zonata (Fig. 6) (Timoshkin et al., 2016). In September-October 2015-2016 the blue-greens abundantly developed on the shore line rocks and nearby, at the depths 0.2-0.5 $\mathrm{m}$, at Bolshye Koty (Fig. 7). This trend of the mass benthonic blue-green development in the coastal zone of entire Lake has continued in 2017-2018. For example, they absolutely dominated (in combination with diatoms) in the algal communities at the "Drizhenko expedition bank" (east coast of the north basin) (Fig. 8). Since the encrusting Baikalospongia spp., which were dominating here did not look healthy and branched Lubomirskia baikalensis were found to be either sick or damaged, possibility of the mass blue-green blooms on the sick encrusting sponges cannot be ruled out. Such examples of the mass blue-green development on the completely destroyed Baikalospongia sp. bodies was found at the rocks near Bolschoy Cheremshanyi Cape (Fig. 9). The wet biomass of Tolypothrix spp. (abundantly covered by attached diatoms) on the depth 11-12 $\mathrm{m}$, near Bolschoy Cheremshanyi Cape, September 29, 2018 , counted by stone unit method, may exceed 240 $\mathrm{g} / \mathrm{m}^{2}$.

The «saprophytic» representatives of Phormidium and Oscillatoria genera, dwelling in Baikal, are not able to fix the atmospheric nitrogen. Their development is evidently limited by nitrogen. This limitation does not exist near the dying sponges and macrophytes. Their destroying bodies extract abundant nutrients $(=$ special 

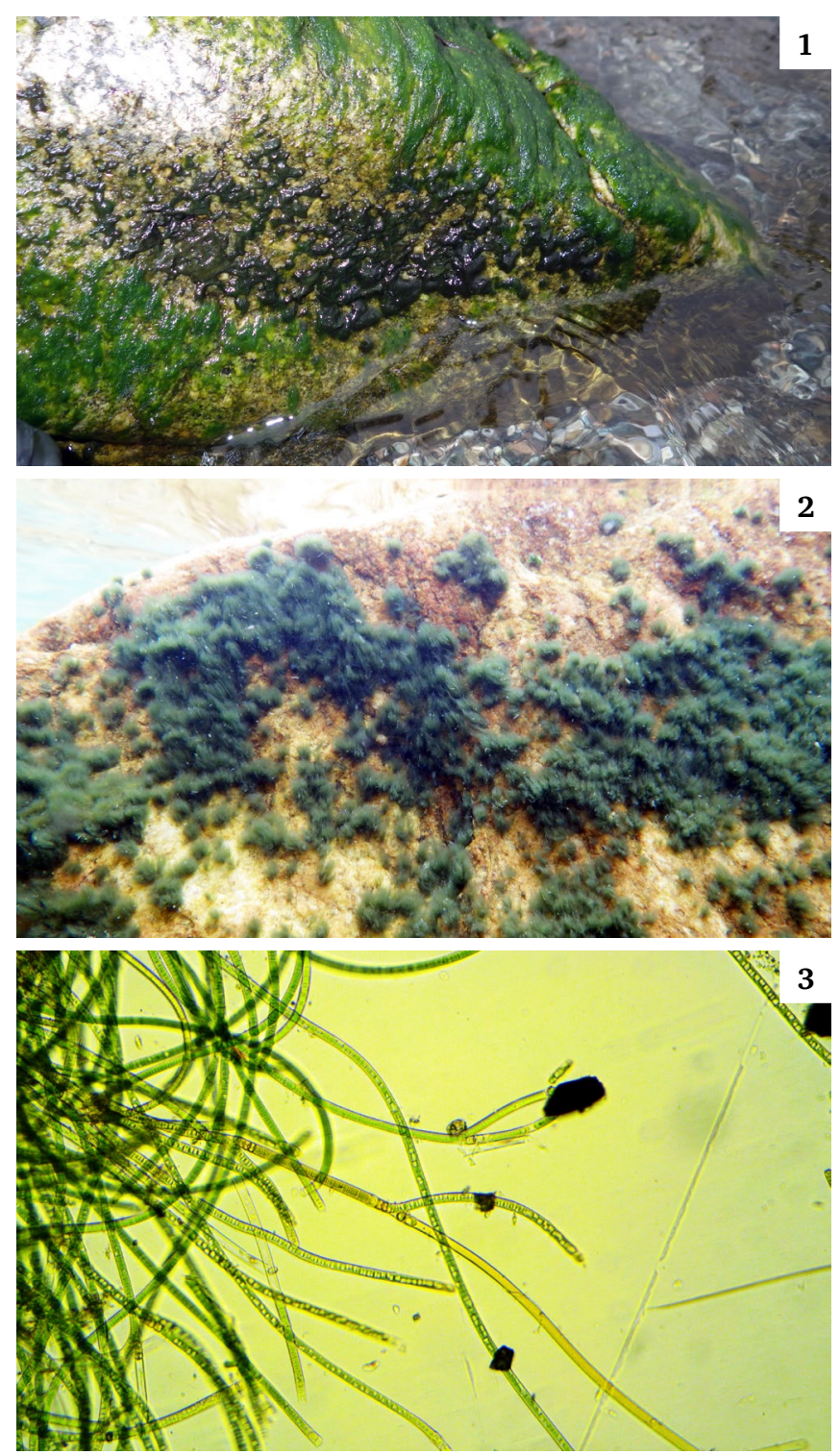

Fig. 6. Mass development of benthonic blue-greens (Tholypothrix distorta) within the Ulothrix zonata belt. Bolschye Koty Bay, August 31, 2016. 1, 2- above-water and underwater views of the colonies respectively; length of the blue-green spot on 1 - ca. $20 \mathrm{~cm} .3$ - light microscopic image of the Tolypothrix distorta branch, ca $1.1 \mathrm{~mm}$ in the length.

type of eutrophication!) (I.V. Tomberg, O.A. Timoshkin, unpublished), which can be easily utilized by the «saprophytic» blue-greens what provides possibility for their mass proliferation. Vice versa, the most evident reason of «free-living» blue-green proliferation (which are able to fix N) is "indirect and forest fire eutrophication" first of all due to additional non-organic phosphorus input through the inlets and ground waters.

According to O.I Belykh (pers. comm.), both types of the cyanoprocaryotes are able to produce different toxins (including saxitoxins). Such abundant blooming of Oscillatoriales in general and within the first algal belt in particular has never been detected in the lake before.

5. Mass Gastropoda mortality (mostly - representatives of Lymnaea genus) is regularly detected in 20132018: billions of died shells found on the sandy beaches between Tyya River and Senogda Bay at the north top of Baikal. These "cemeteries" are located along the are-
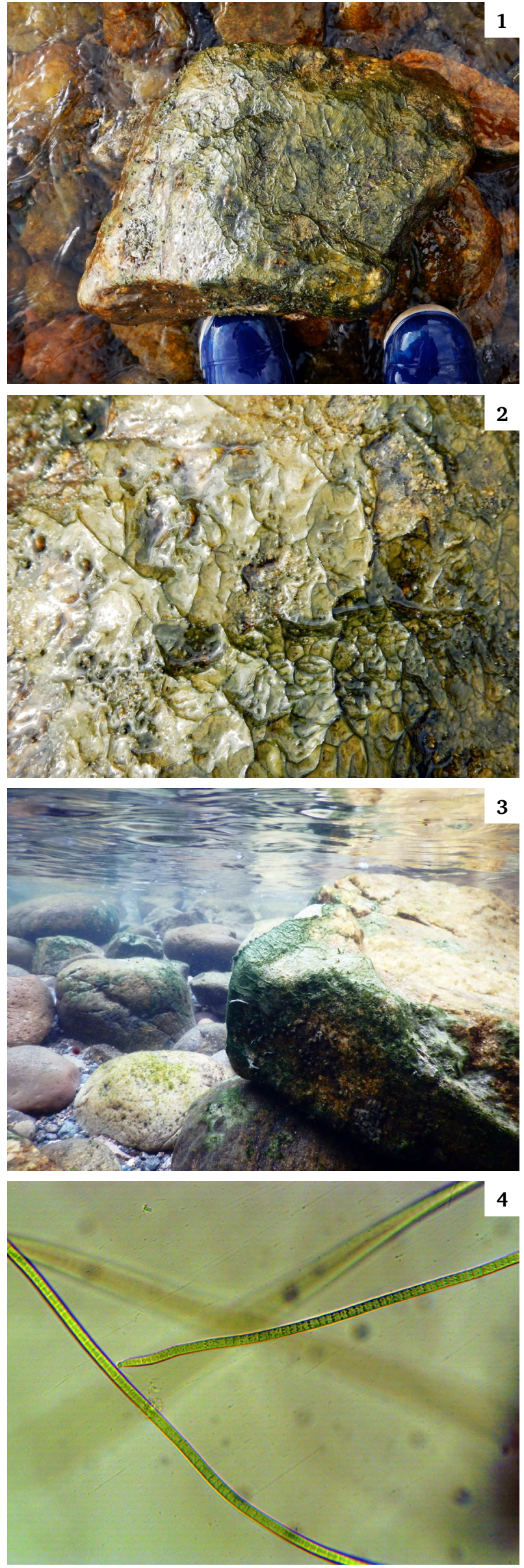

Fig. 7. Mass development of benthonic blue-greens (Phormidium spp.) in the near-shore phytocoenoses of Bolschye Koty Bay, October 23-24, 2016. 1-2 - aerial, 3 - underwater, 4 - light microscopic images of the biofilms and their filaments respectively. Magnification on the $4-$ ca. $400 \mathrm{X}$. 
as of the most abundant Spirogyra development, influenced by sewages from Severobaikalsk City. Less abundant Lymnaea shell accumulations found along the splash zone, off Maximikha settlement in Barguzin Bay (June 2015).

6. Mass mortality and several kinds of diseases of endemic Lubomirskiidae sponges at the scale of the entire lake were described in 2013-2018 (Bormotov, 2011; Timoshkin et al., 2014; 2015; Khanaev et al., 2018). All 3 ecological forms of the sponges (branched, encrusting, globular) can be sick. Over than 50 dives performed in 2014, 40 - in 2015. Depending on area, from 30 to $100 \%$ of branched Lubomirskia baikalensis specimens were found to be either sick or damaged and died. According to Dr. Ch. Boedecker (pers. comm.), in most of the studied areas of south basin (September 2014) the sick sponges were usually found at the depths above 15-20 m. However, deeper leaving sick specimens of the branched sponges were found already in June 2015 and later on.

It was described, that the most distributed sponge illness is accompanied by mass development of the "saprophytic" Phormidium-shaped blue-greens (Timoshkin et al., 2015). Their filaments are comparatively large, cherry-red and mobile. Light-microscopic analysis evidences, that each affection patch on the sponge surface consists of 1-2 dominating blue-green species (90-95\%). Different deformations and damages of the external surface of the sponge body ( = initial stages of their bodies destruction) in most cases happen prior to the mass blue-green development. According to preliminary data, the branched sponges, dwelling in the south basin (Listvyanichny, Bolshye Koty Bays, off Chernaya River mouth) are most of all affected by illnesses. For example, almost 100\% of Lubomirskia baikalensis specimens, dwelling off Chernaya River mouth along the standard bottom transect (South Baikal, 1 $\mathrm{m}$ wide and $10 \mathrm{~m}$ long; at the depths 3-12 $\mathrm{m}$, during 2014-2015) were either damaged, or thick and died (A.B. Kupchinsky, S. Aurich, pers. comm.). Much less damaged or even healthy $L$. baikalensis specimens were found in September 2014 around the north-western coast; area, approximately located between Elokhin Cape and Bolshye Olkhonskye Vorota.

As shown earlier, the same blue-green morphotypes used to dwell on the destroying thalli of Draparnaldioides macrophytes at the end of their vegetation season (Timoshkin et al., 2012). The mass development of the blue-greens began from the basal parts of the algal thalli (attached to the rock) and gradually covers all the thallus (Figs 5, 9.1). Surely, the mass proliferation of similar morphotypes of Oscillatoriales on the destroying Baikal endemic sponges and macrophytes has the same pattern and reasoning. Mass necrosis of the algal ${ }^{9}$ and sponge bodies may supply the "saprophytic" blue-greens by essential nutrients (nitrogen, for example), what could significantly stimulate their

9 Mass blue-green development on thalli of Draparnaldioides baikalensis in Bolshye Koty Bay was regularly detected in September-October 2007-2018. L.A. Izhboldina (2007) described several Phormidium spp., developed at the basis of Draparnaldioides pumila.
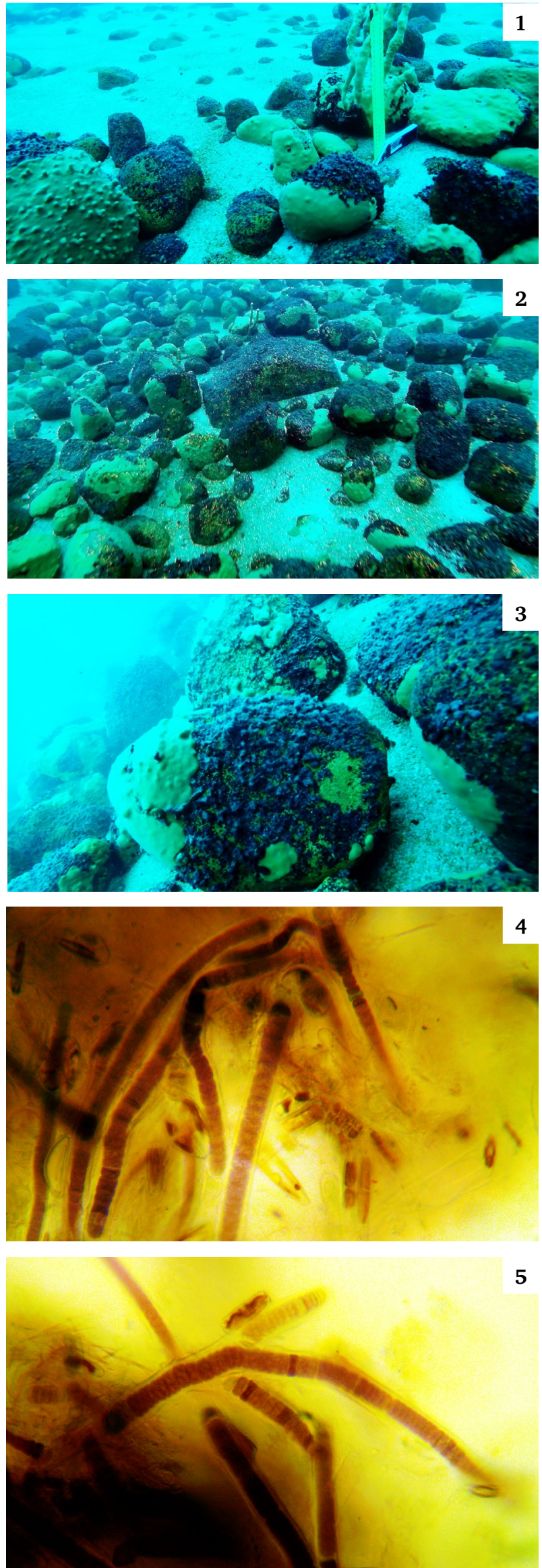

Fig. 8. "Kingdom" of blue-greens and encrusting sponges at the "Drizhenko expedition bank", opposite Frolikha Bay (east coast of the north basin), September 28, 2018, depth 11-12 m. 1-3 - underwater views of the landscape and the rocks, covered by blue-greens and Baikalospongia spp. 4-5 light-microscopic image of the blue-green filaments (Tolypothrix sp. ?). Magnification ca. $400 \mathrm{X}$. 
mass development. Earlier, in 2003-2004, mass development of Oscillatoriales on sponges was time to time detected in south and middle basins ${ }^{10}$ on the encrusting and branched Lubomorskiidae (Izhimey Cape, 2004). Small areas of the sponge bodies (several $\mathrm{cm}^{2}$ ) were covered by dark-red or brown biofilms (Fig. 10). But during all period of our previous investigations (20002008) I have never seen the completely sick/damaged/ died sponge bodies as in 2010-2018. Possibly, the blue-greens developed on the damaged (or - naturally dying) body portions of the sponges and never caused their mortality. During Lubomirskiidae mass extinction the development of the "saprophytic" oscillatoriales also became abundant.

The reasoning of the mass development of the "free-living" blue-greens in the benthos needs a special analysis, what is currently in the progress and will be published elsewhere.

The precise reasons of the mass Lubomirskiidae mortality are to be clarified. To my mind, one of many suppositions made earlier deserve the special attention. As hypothesized earlier (Timoshkin et al., 2015), the most probable reason of this phenomenon might be the physiological abnormalities in the relations between the endosymbionts (such as green Zoochlorella) and the sponge proper. Some precise processes and nutrient exchange mechanisms between algal symbionts and the sponge cells, elaborated during the long coevolution and coexistence in the oligotrophic waters, may be easily broken due to miserable but permanent addition of the sewage nutrients. It may cause the destruction of the sponge bodies, which has been detected so frequently. Analogous processes, causing the mass death of another sedentary lower Metazoan group - corals (which as well coexist with endosymbiotic blue-green algae), also inhabiting oligotrophic ecosystem of the ocean, are happen due to miserable but permanent eutrophication process (Yamamuro et al., 2003; Bell et al., 2014). For another potential reason - see section 5 .

7. Numerous dead bodies of the endemic gammarid Macrohectopus branickii, exclusively dwelling in pelagic zone deeper than $150 \mathrm{~m}$, were found in the splash zone and near shore algae aggregations of Senogda Bay in September 2018 (Fig. 11). Most of the crustaceans belonged to the adult females (ca $2 \mathrm{~cm}$ long), which normally create the aggregations and avoid the shallow water zone. The reasons of their mortality are not clarified yet.

8. High concentrations of the fecal indicating bacteria have been determined in the surface and nearthe-bottom water layers along the coasts opposite the settlements. The same is true for the interstitial waters (especially - under the coastal accumulated algae) of the splash zone. For example, the enterococci concentrations often exceed 2000 colony forming units per $100 \mathrm{ml}$ (V.V. Malnik, pers. comm.).

\subsection{Invasive and non-indigenous species}

Invasive and non-indigenous species first of all appear in the coastal zones of the lakes, often evidenc10 No data on the sponges of the north basin available so far.
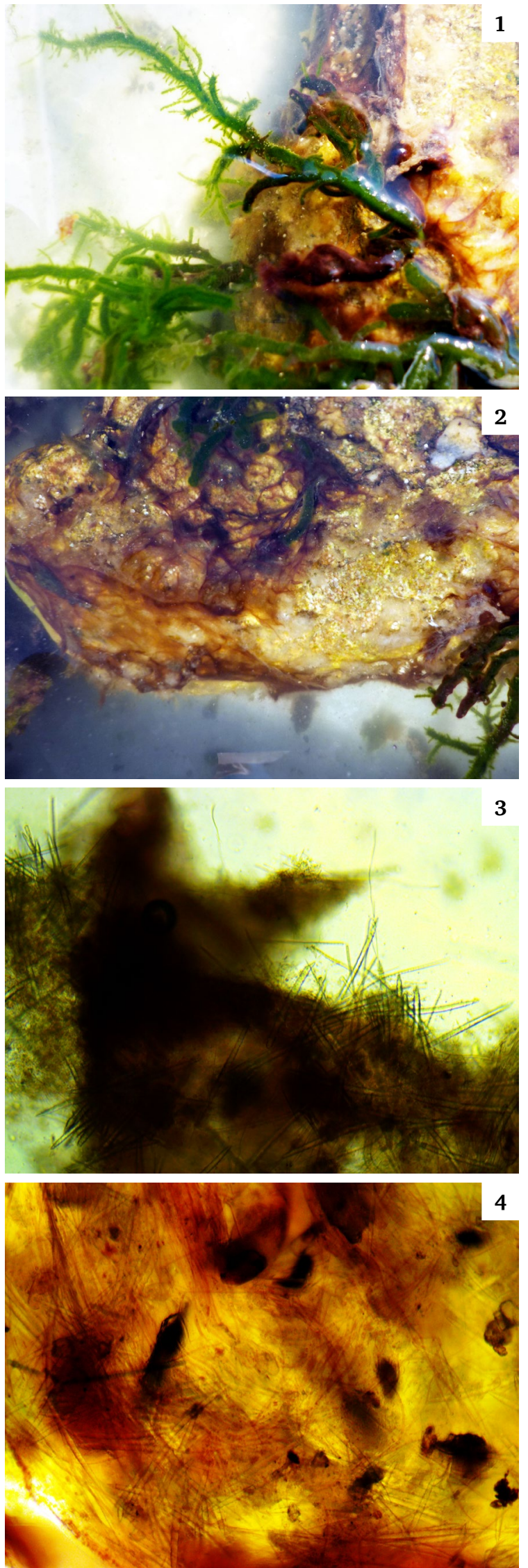

Fig. 9. Mass development of the saprophytic blue-greens. $\mathbf{1}$ - on the dying thalli of Draparnaldioides sp.; $\mathbf{2}$ - brown red biofilm on the completely destroyed Baikalospongia sp. (whitish spot from the right: the biofilm was partly removed to show the destroyed sponge body). 3, 4 - light-microscopic image of the blue-green filaments and sponge spicules. Magnification ca. 100 X. September 29, 2018; 1 mile south of Bolschoy Cheremshanyi Cape: 54035.857' N; 108043.075'E; the same stone unit. 
ing on the early stages of ecological disturbances in lacustrine ecosystems. They can easily be detected if the process of regular survey (monitoring) has been performed. During last 10-15 years, the following species became abundant and even dominating the coastal zone communities of Baikal: filamentous green algae of Spirogyra genus, gastropod mollusks of Palearctic Lymnaea genus (in particular - Lymnaea (Radix) auricularia (L.)), riverine caddis flies Apatania majuscula McL., Hydatophylax nigrovittatus (McL.) (Fig. 12) (Sitnikova T.Ya, pers. comm., own observations; Kravtsova et al., 2012; Timoshkin et al., 2016; 2018; Rozhkova et al., 2018). Due to the multi-year monitoring of the coastal zone Trichopteran species, performed by Dr. Rozhkova N.A. and Dr. Nepokrytykh A.V., we know, that these species first penetrated the coastal zone of the south basin and currently they are spread and rapidly expanding this zone in some areas of the middle basin.

\section{Interrelationships of plankton and benthos development are most apparent in the coastal zone}

Well known, that water ecosystems, following the environmental cycles (solar radiation, temperature, etc.) may demonstrate the regular cycles in their development. Their graphical representations can be compared with cordial rhythm. The best known "cordial rhythm" in Baikal pelagial - the phenomenon of "Melosira years", which took place every 3-4 years (Fig. 13) and characterized by intensive mass proliferation of typical for open Baikal planktonic Aulacoseira diatoms and other algae (Antipova and Kozhov, 1953; Evstafiev and Bondarenko, 2002a; b; etc.). Phytoplankton cycles determine the cycles in zooplankton development (for summary, see: Kozhov, 1963; Guide and key to pelagic animals..., 1995). It seems perfectly clear that the cycles in phytoplankton growth are evidently related to zooplankton life cycles and even determine them. It is well-known for Baikal researchers (ab. cit.). Several distinct abundance and biomass peaks in the phytoplankton growth pattern suggest similar fragmentary and inhomogeneous inputs of organic carbon from the pelagial zone to the lake bottom where it becomes available for primary benthic consumers. It means that quantitative characteristics of benthic Baikal communities should likewise be discrete and non-uniform in both perennial and seasonal aspects. These processes are particularly prominent in the littoral communities and most illustrative during ice cover period. We found, that the first, meroplanktonic stage of Aulacoseira baicalensis development clearly expressed in and beneath the ice cover in the coastal zone (Timoshkin, 2001). Mucous cords and filaments, attached to the lower side of the melting ice (March 2000 , Berezovy test site), from several $\mathrm{cm}$ to $2.5-3 \mathrm{~m}$ in the length (Figs 13, 14), demonstrate unusual for this low water temperature growth rate $(1-3 \mathrm{~cm}$ per day: Timoshkin et al., 2000; Timoshkin, 2001). The cords mostly consist of Aulacoseira filaments and, in combination with abundant invertebrate in- and epifauna, rep-
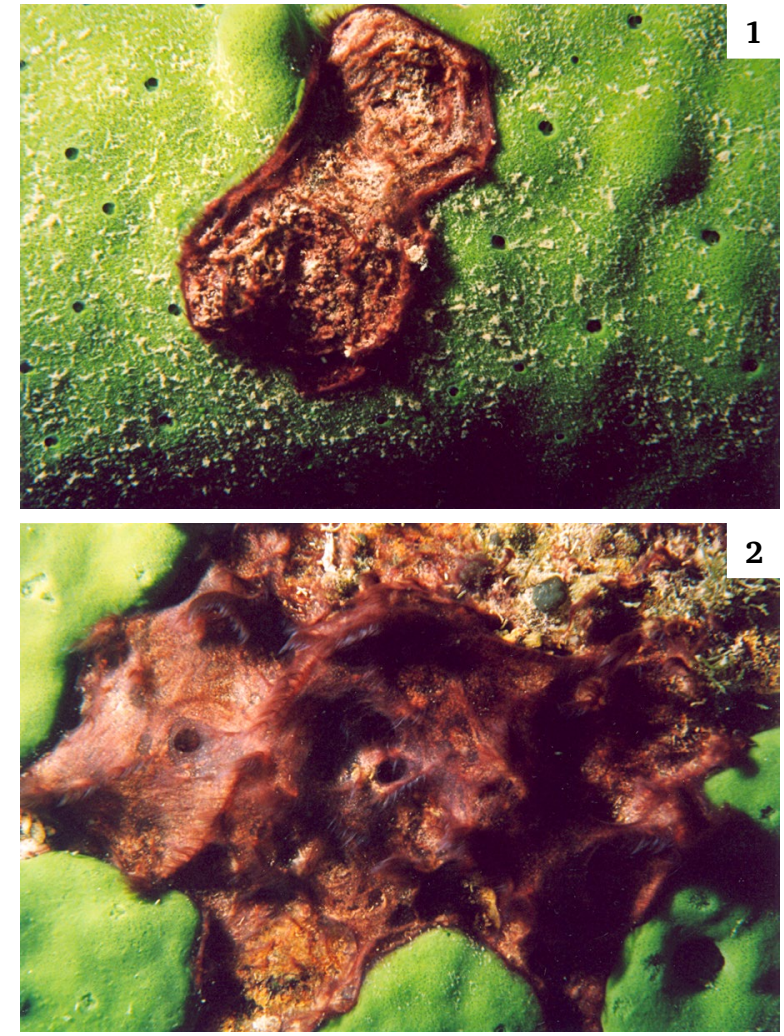

Fig. 10. Phormidium-shaped blue-greens (dark-red spots) on the surface of Baikalospongia sp., so-called pre-crisis period. 1-2 - photos taken along to the standard transect "T0" on Berezovy test-site, South Baikal, station 0.2, depth 2-2.4 m; October 27, 2004. Underwater photos taken by NIKONOS-V with SEA\&SEA 35M-3 attached macroring; film No 1632; frame numbers $22 ; 25 \mathrm{~A}$; the total area of each of the frames: $110.5 \mathrm{~cm}^{2}$.
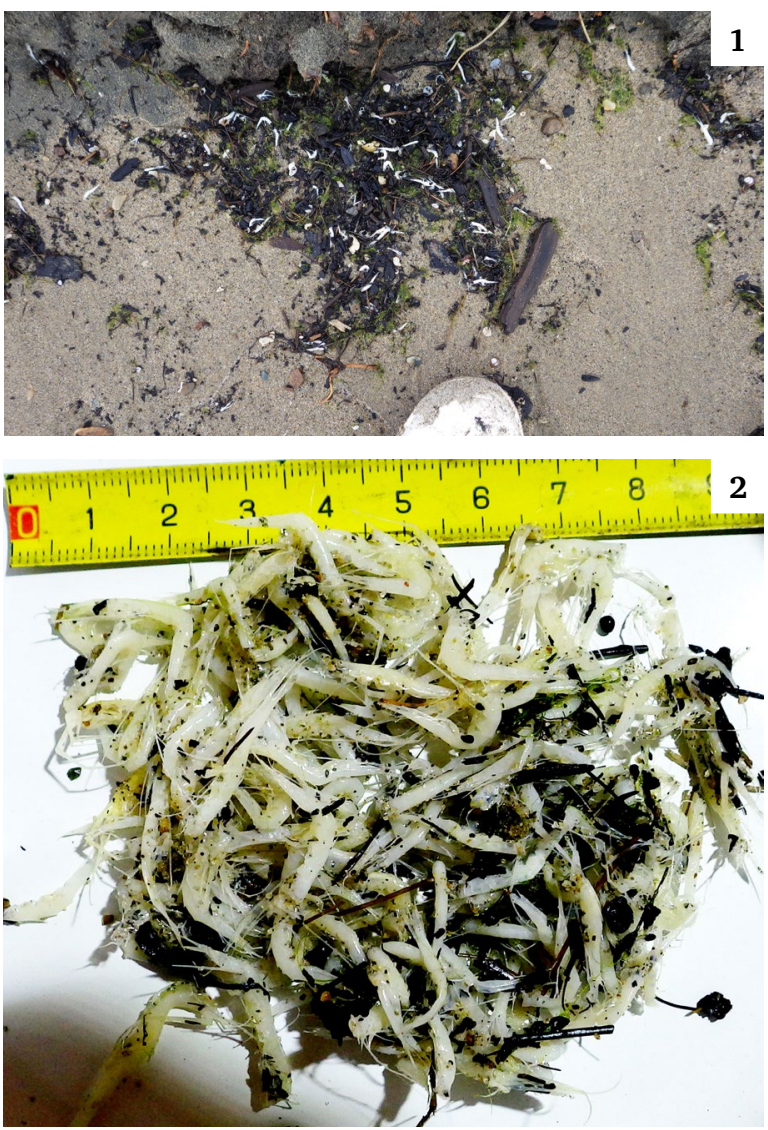

Fig. 11. Died bodies of the pelagic amphipod Macrohectopus branickii along the shoreline of Senogda Bay, north basin. September 27, 2018. 
resent cryophilic community No 2 (sensu Timoshkin, $2009^{11}$ ). The period of mass sinking of these cords and filaments onto the bottom in late March-April usually correlates with migration of the giant abyssal triclads to the coastal zone (for laying cocoons), mass hutching of young endemic gastropods. Reproduction of some crustacean, mollusks and cottoid species (Taliev, 1955; Kozhov, 1963; Sideleva and Nagorny, 1985); hutching of the coregonid larvae and their downstream migrations into the lake's coastal zone (Chernyaev, 1982) are confined just to this period. Evidently, the pelagic and bottom communities in the coastal zone demonstrate a certain degree of synchronic development, which can be expressed in mutual co-adaptations of the life cycles of the dominant species, peaks of their maximum abundance and/or biomass, etc. (Timoshkin et al., 2000). For more clear correlation we need to know the multiyear "cordial rhythm" of benthos development, which currently is lacking. Thinking of the optimal scheme of Baikal ecosystem monitoring, one should consider this possibility of synchronic development of plankton and benthos in the coastal zone.

The current irregularity of Melosira years (and their almost complete absence in South Baikal since 2007: Bondarenko and Logacheva, 2016) can be explained (at least, in part) by the rapid ecological changes, which sharply expressed first of all in the coastal zone (for summary, see Timoshkin et al., 2016).

\section{Bioconcentration and bioaccumulation of pollutants in coastal benthic plants and animals}

As shown earlier (Timoshkin et al., 2016), the specific composition of POP in the interstitial waters of Baikal splash zone can be used as a perfect markers of sewage pollution in Severobaikalsk vicinities. Important conclusions, regarding the POP distribution and bioaccumulation in the coastal zone communities were made during the collaborative NPO TAIFUN-LIN SD RAS expeditions and research (2014-2015) (Persistent..., 2017; Samsonov et al., 2017). ${ }^{12} 1$ ) In all cases the specific POP concentrations in different coastal algae and invertebrates were significantly higher as compared to their concentrations in the water. It evidences on their high ability to accumulate and bioconcentrate the organic pollutants. 2) Entire spectrum of organochlorine pesticides, found in Baikal waters so far, were identified in the coastal algae. The concentrations of some OSP's (i.e., toxaphenes, nonachlores, DDE) in algal dry mass may exceed the analogous concentrations in water 1000-5000 fold. 3) Based on POP analyses in Baikal hydrobionths, other than fishes (Gorshkov et al., 2017) (see the footnote 12), it was confirmed that the POP concentrations in their bodies may ex-

11 In total, four types of the cryophilic communities were described depending on their dominant species. Two of them are characterized on the Figs 13-15.

12 Costal algae (Ulothrix zonata, Spirogyra spp.), encrusting and branched sponges, gastropods, amphipods of Acanthogammarus genus were analyzed.
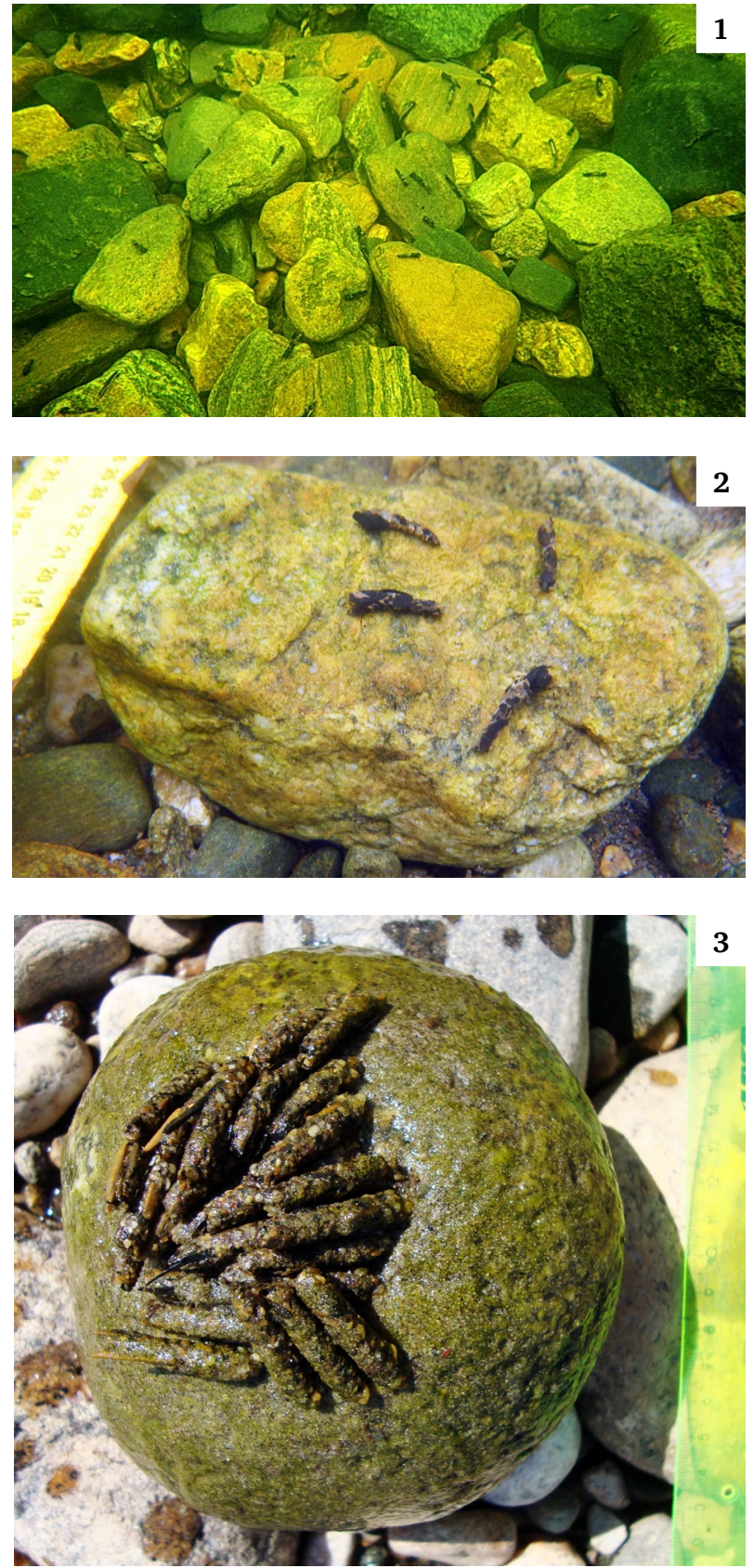

Fig. 12. Numerous larve $(1,2)$ and pupae (3) of formerly rheophilic caddis fly Hydatophylax nigrovittatus (McL.), which currently occupied the coastal zone of open Baikal. 1, 2 September 18, 2018, opposite of Kultuk Settlement, depth 1 m; 3 - June 13, 2013, opposite of Baikalsk cellulose plant combinat, 1.5 m. Identification of Dr. Rozhkova N.A., Dr. Nepokrytykh A.V.

ceed analogous concentrations in surrounding waters in hundreds of one times. In particular, we have found that the PCB concentrations in Lubomirskiidae bodies may exceed their concentrations in the water column 100-1000 fold! For example, the total PCB concentrations in the body of the branched sponge Lubomirskia baikalensis varied within 3.0-19.1 (on average, 9.16) $\mathrm{ng} / \mathrm{g}$ of the dry weight; while their concentration in the surface waters vary within $1630-4860 \mathrm{pg} / \mathrm{dm}^{3}$ (Persistent..., 2017). Therefore, it is a reasonable working hypothesis to suggest that high concentration of organic pollutants (including POP) in Lubomirskiidae bodies potentially may cause their illnesses and mortality. Another example - endemic benthonic side-swimmers 

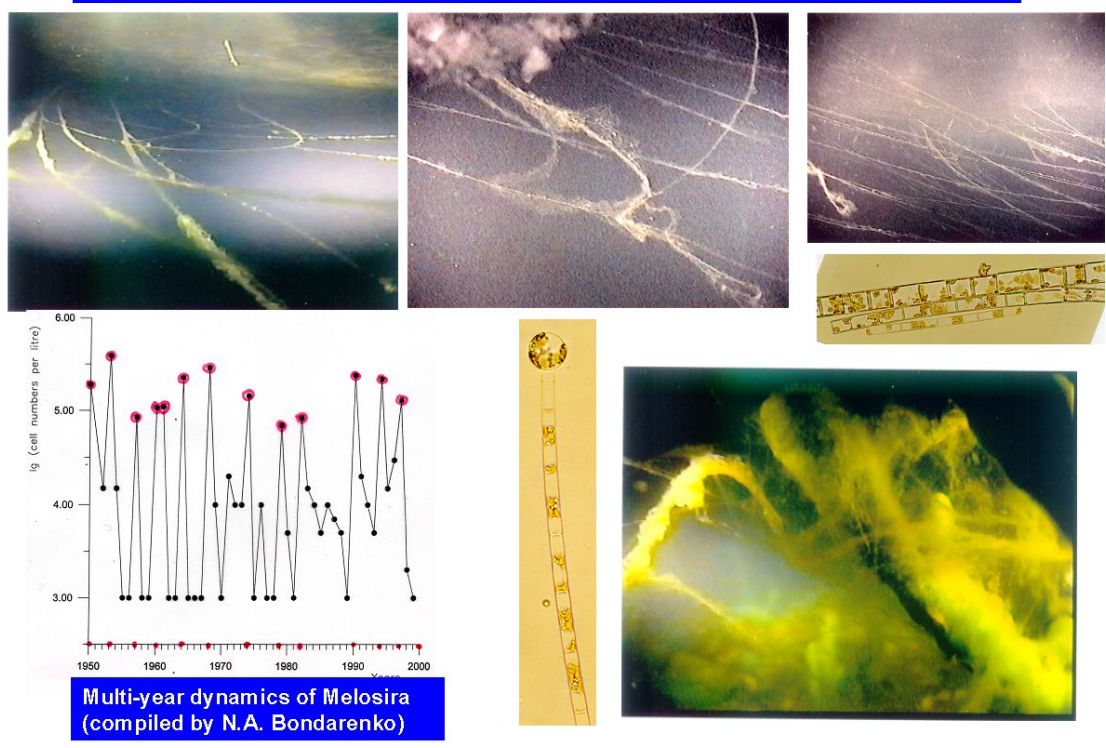

Fig. 13. "Melosira cordial rhythm" in Baikal pelagial; graph in the left lower corner (compiled by Dr. Bondarenko N.A.); three upper photos: "ice community No 2" - under-ice filaments, mostly consisting of Aulacoseira baikalensis; intermediate narrow photos - light microscopic images of Aulacoseira sp.; Lubomirskia baikalensis branches, covered by the merged down to the bottom ice algal filaments, right lower corner (after Timoshkin et al., 2009).

of Acanthogammarus genus. All types of organochlorine pesticides, found in Baikal waters so far, were also detected in the gammarid bodies. Some of the specimens analyzed demonstrate the highest values of pesticides ever detected in Baikal fauna: DDT metabolites - over $1200 \mathrm{ng} / \mathrm{g}$ of lipids; PCB (polychlorinated biphenyls) - over $4000 \mathrm{ng} / \mathrm{g}$ of lipids. According to our unpublished data, Acanthogammarus sp., which was analyzed, belongs to hunters and/or necrophages (top level in the trophic chains). This factor may determine such a high pollutant concentrations in their bodies.

Besides measurement of POP and other pollutant concentrations in the waters, soils, sediments, we have to elaborate the list of indicative coastal Baikalian algae and invertebrates which are able to accumulate and concentrate these pollutants and promote this species list as a basement for the regular optimized monitoring scheme.

\section{How the stable hydrochemical status of the water column may correlate with "casual" understanding of the term "eutrophication"?}

Eutrophication of average lake, in common sense, usually characterized by increasing the trophic

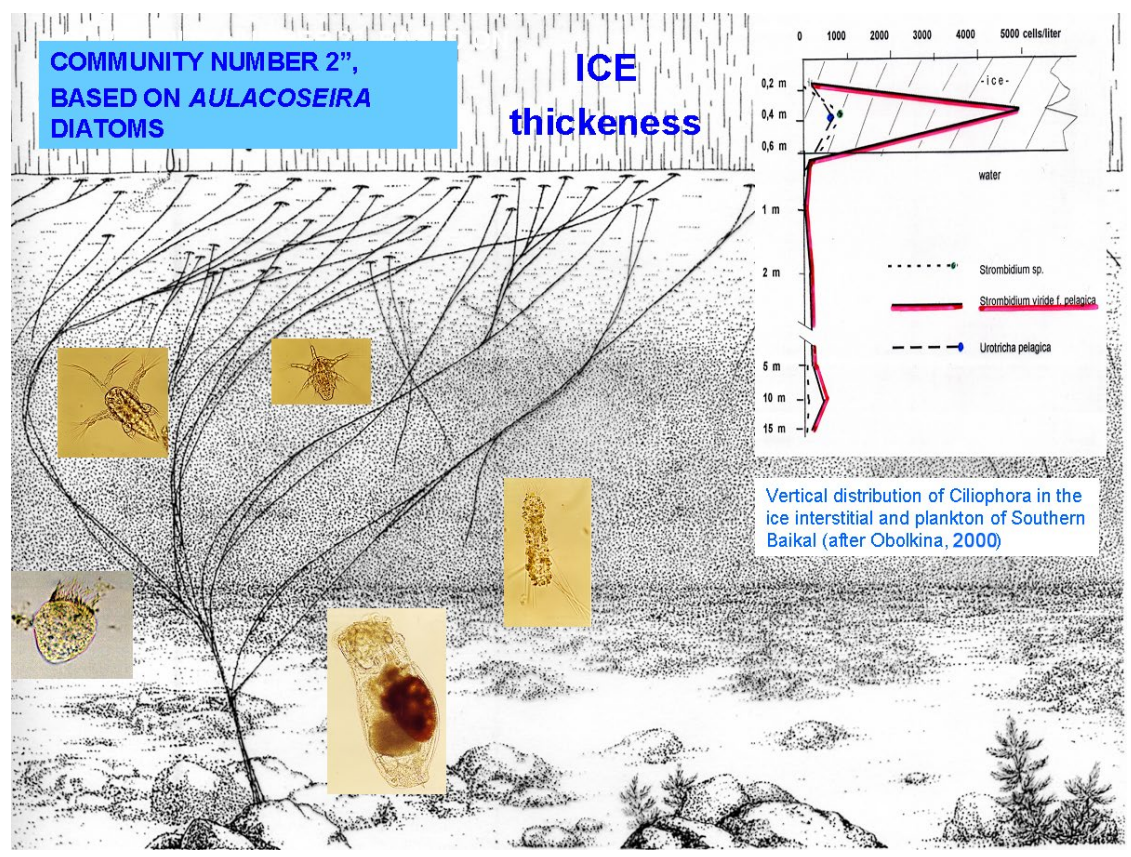

Fig. 14. "Ice community No 2" - under-ice filaments, mostly consisting of Aulacoseira baikalensis; reconstruction made by help of underwater video records, taken on the depth ca. $3 \mathrm{~m}$, Berezovy test-site, spring 2001 (after Timoshkin et al., 2009). Upper graph from the right: vertical ciliophora distribution in the ice interstitial waters (after Obolkina et al., 2000; Obolkina, 2003). 


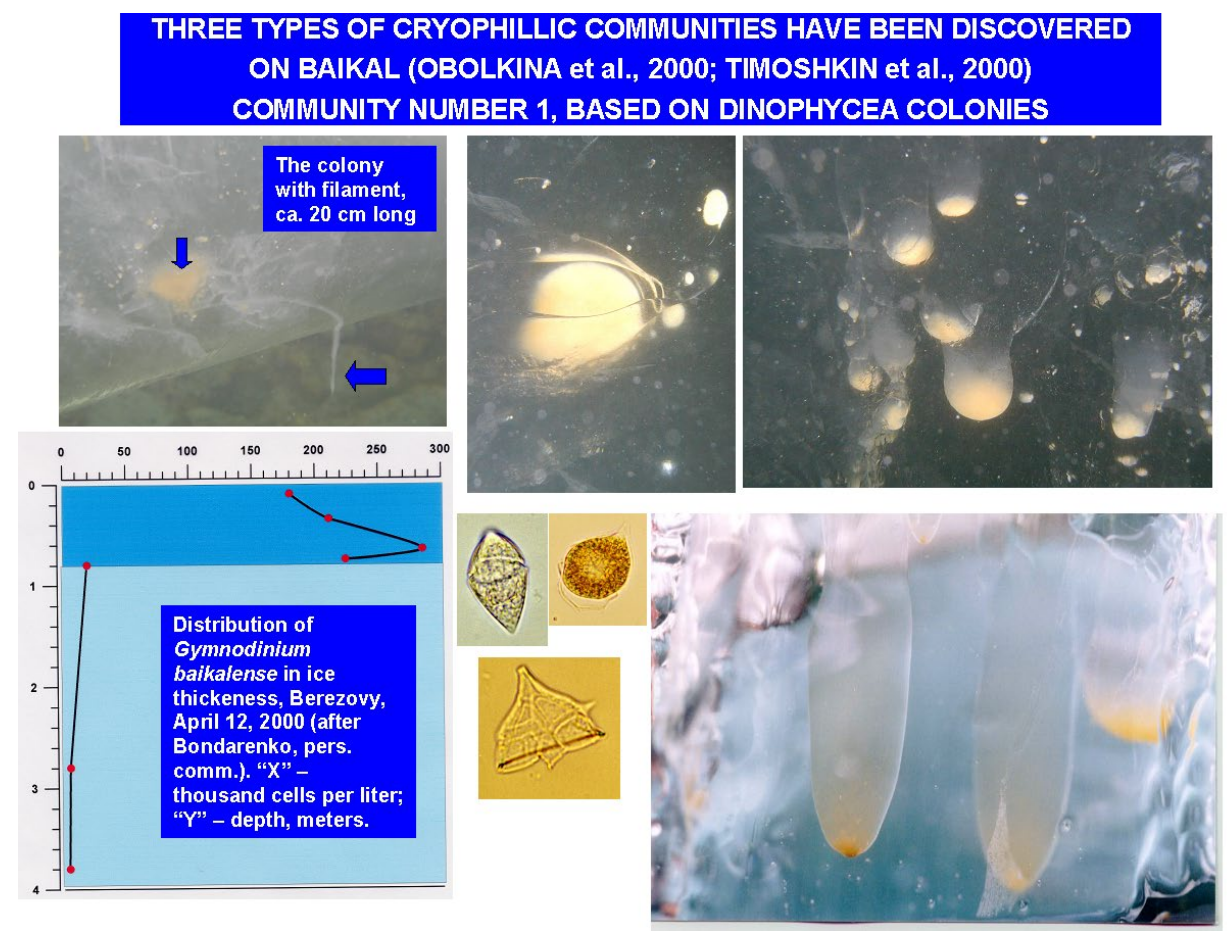

Fig. 15. "Ice community No 1". Upper and right photos - ball- and finger-shaped cavities within the ice thickness, filled up by Gymnodinium cells (after Timoshkin et al., 2009). Light-microscopic images of the algal shells (photos by Bondarenko N.A. in the middle) and the Gymnodinium distribution inside the ice thickness, left lower corner (data of Bondarenko N.A.).

status of the water body due to nutrient enrichment, elevated nutrient concentrations in water column, lowering of transparency and dissolved oxygen concentrations due to increased abundance of phyto- and zooplankton, mass development of planktonic bluegreens, etc. Negative ecological processes observed in Lake Baikal do not feet in with the commonly accepted picture of "casual eutrophication": most hydrochemical parameters (including the nutrient concentration, dissolved oxygen, transparency) of the main water masses are stable; the trophic status, in general, has not been changed (yet). Therefore, many scientists do not believe that the eutrophication in Baikal is currently in progress - they just keep in mind the standard "eutrophication picture", described above. Nonetheless, the deep degradation of the coastal zone communities is evident (see above) and to my deep believe, mainly caused by eutrophication. The following main "eutrophication sources" can be distinguished with regard to Baikal ecosystem: "casual eutrophication" of the inlets and near shore settlement waters (1), contamination of the ground waters and the interstitial waters of the splash zone (2) by sewages; secondary contamination due to algal wash ups decaying (3); mass extinction of endemic Lubomirskiidae sponges (4); numerous coastal taiga fires (5); aerosol contamination (6).

\section{Landscape-ecological approach and the universal scheme of the great lakes monitoring}

Karabanov E.B. was the first researcher, who introduced the landscape-ecological approach into Baikal limnological survey (Karabanov et al., 1990). He elaborated the landscape-ecological zonation of entire Lake Baikal, which included 61 bottom landscapes and
11 physical-geographical regions of the water body. The most species-rich coastal zone was subdivided into eight landscapes only. This zonation provided reasonable scientific basement for establishment the set of standard test-sites and transects for regular observations. Following his ideas and considering landscapes as universal units of natural organization and as a fundamental basis for standardized monitoring schemes, Timoshkin et al. (2005) elaborated and proposed the universal scheme of the great lakes monitoring based on the landscape-ecological approach. Because the anthropogenic impacts may influence biota at all levels of organization (communities $\rightarrow$ populations $\rightarrow$ organisms $\rightarrow$ cells $\rightarrow$ molecules), biotic monitoring should cover each level. In practice, methods used commonly to investigate community and population structure, dynamics of dominant species, teratic species and genetic diversity, including chromosome aberrations, should be applied. Following this landscape zonation, we have established 8 standard transects along to the coastal zone of entire lake and performed more or less regular investigations since 2004. Detailed description of the monitoring scheme and main results are given in Timoshkin et al. (2009) and partly presented here.

\section{Conclusion}

Coastal zone of the large lakes surely deserves the special attention of limnologists. The gap of our knowledge on the ecology of this zone should be covered as soon as possible.

The uniqueness of Lake Baikal makes the ongoing eutrophication different from all other Palearctic lakes. Therefore, the hydrochemical and other indicators of the water column of great lakes do not match the principal eutrophication criteria pool. Biological 
indication approach in the coastal zone appears more appropriate for the prompt detection and analysis of the initial eutrophication stages in the large lakes. Obviously, the pelagic zone and pelagic communities of the giant lakes are much more conservative, stable and quite resistant to anthropogenic impact as compared to the coastal zone.

The governmental monitoring schemes of the large lakes of the planet are often not effective due to "superconcentration" of the efforts exclusively on the pelagial. In order to detect, understand the reasons and properly describe the anthropogenic changes of the ecosystems at the full scale we have to pay a special attention to the monitoring of the coastal zone (the splash and near-shore zones including) and, especially - to the benthonic communities. As distinct of plankton, the precise investigations and monitoring of zoobenthos is almost "extinct direction" in limnological surveys of many countries.

\section{Acknowledgements}

Investigations were funded by the Federal Projects of the Siberian Branch of the Russian Academy of Sciences, supervised by the author: "Interperiodicity of the development of plankton and benthos communities - the key to understand the functioning of Baikal ecosystem (Berezovy test-site as a target area)" (2000-2003); "Investigations of biogeochemical processes in the littoral of Lake Baikal: biodiversity in benthos, hydrobiont preferences to minerals, biodestructive mechanisms, principal benthic communities and their interrelations with the habitat" (2004-2006); 7.9.1.3 "Impact of landscape-ecological factors on the formation of biodiversity, unique communities and speciation processes in the coastal zone of Lake Baikal" (2007-2009); VII.62.1.4. "Interdisciplinary research of the splash zone as important constituent part of Baikal littoral" (2010-2012); VI.51.1.10 "Current state, biodiversity and ecology of the coastal zone of Lake Baikal" (2010-2012), the Grants-in-Aid for Scientific Research (KAKENHI) (Japanese-Russian no. 15H05112 - to Prof. M. Yamamuro and OAT). The preparation of this review was supported by the federal project No. 03452016-0009 "Large-scale changes in ecology and biodiversity of coastal zone communities of Lake Baikal: interdisciplinary research, reasoning and prognosis" (2017-2020). I am thankful to all staff members of the laboratories of invertebrate biology, biogeochemistry and hydrochemistry of LIN SD RAS, to the crew members of RV "Koptyug", "Papanin" for their tremendous help in collaborative research and expeditions. Special thanks are due to E.M. Timoshkina for English translation of the abstract, Dr. A.A. Shirokaya for the assistance with preparation of References, A.G. Lukhnev for assistance with temperature measurements, Dr. E.P. Zaitseva is thanked for blue-green wet biomass counting, V.I. Chernykh and I.V. Khanaev for diving samples (all - LIN SD RAS). E. Yakushina (Worley Parsons Ltd., Canada) kindly provided some consumables for our research and expeditions.

\section{References}

Agafonov B.P. 2002. Broaden Baikal. Doklady Earth Sciences 382: 540-542. (in Russian)

Antipova N.L., Kozhov M.M. 1953. Materials on the seasonal and annual fluctuations in the crop of some widespread forms of phytoplankton in Lake Baikal. Trudy Irkutskogo Universiteta [Proceedings of the Irkutsk University] 7: 63-68. (in Russian)

Bell P.R.F., Elmetri I., Lapointe B.E. 2014. Evidence of large scale chronic eutrophication in the Great Barrier Reef: quantification of chlorophyll "a" thresholds for sustaining coral reef communities. AMBIO 43: 361-376.

Bondarenko N.A., Timoshkin O.A., Röpstorf P. et al. 2006. The under-ice and bottom periods in the life cycle of Aulacoseira baicalensis (K. Meyer) Simonsen, a principal Lake Baikal alga. Hydrobiologia 568: 107-109. DOI 10.1007/ s10750-006-0325-7

Bondarenko N.A., Logacheva N.Ph. 2016. Structural changes in phytoplankton of Baikal coastal zone. Hydrobiological Journal 6: 17-26.

Chernyaev Zh.A. 1982. Baikal omul reproduction. Moscow: Legkaya I pischevaya promyshlennost Publ. (in Russian)

Evstafiev V.K., Bondarenko N.A. 2002a. The nature and patterns of the "Melosira Years" phenomenon in Lake Baikal. Hydrobiological Journal 38: 3-12. (in Russian)

Evstafiev V.K., Bondarenko N.A. 2002b. Why is it so that Aulacoseira baicalensis is highly abundant during even solar cycles, whereas Aulacoseira islandica is highly abundant during odd solar cycles? Biophysics 5: 943-944. (in Russian)

Gorshkov A.G., Kustova O.V., Dzyuba E.V.et al. 2017. PCB in the water ecosystem of Lake Baikal. Khimiya v Interesakh Ustoichivogo Razvitiya [Chemistry for Sustainable Development] 25: 269-278. (in Russian)

Great Lakes Water Quality Agreement (GLWQA). 2012. Protocol amending the agreement between Canada and the United States of America on Great Lakes Water Quality [binational.net/2012/09/05/2012-glwqa-aqegl/]

Guide and key to pelagic animals of Baikal. 1995. In: Timoshkin O.A. (Ed.). Novosibirsk: Nauka. (in Russian)

Guseinov M.K. 2005. Zoobenthos communities of Dagestan district of Caspian Sea. Biologiya Morya [Russian Journal of Marine Biology] 31: 17-22. (in Russian)

Hampton S.E., Izmest'eva L.R., Moore M.V. et al. 2008. Sixty years of environmental change in the world's largest freshwater lake - Lake Baikal, Siberia. Global Change Biology 14: 1947-1958. DOI: 10.1111/j.1365-2486.2008.01616.x

ILEC World Lake Database. 1999-2018. [http://wldb. ilec.or.jp/]

Index of animal species inhabiting Lake Baikal and its catchment area. 2001-2011. In: Timoshkin O.A. (Ed.), In 2 Volumes and 4 books. Novosibirsk: Nauka. (in Russian and English)

Izhboldina L.A. 2007. Guide and key to benthonic and periphyton algae of Lake Baikal (meio- and macrophytes) with short notes on their ecology. Novosibirsk: Nauka-Center. (in Russian)

Izmest'eva L.R., Moore M.V., Hampton S.E. et al. 2016. Lake-wide physical and biological trends associated with warming in Lake Baikal. Journal of Great Lakes Research 42: 6-17. DOI: 10.1016/j.jglr.2015.11.006

Karabanov E.B., Sideleva V.G., Izhboldina L.A. et al. 1990. Underwater landscapes of Lake Baikal. Novosibirsk: Nauka. (in Russian)

Kaplina G.S. 1970. Zoobenthos of South Baikal in Utulik-Murino area. Izvestiya Biologo-Geograficheskogo Nauchno-Issledovatel'skogo Instituta pri Irkutskom Gosudarstven- 
nom Universitete 23: 42-64. (in Russian)

Khanaev I.V., Kravtsova L.S., Maikova O.O. et al. 2018. Current state of the sponge fauna (Porifera: Lubomirskiidae) of Lake Baikal: Sponge disease and the problem of conservation of diversity. Journal of Great Lakes Research 44: 77-85. DOI: 10.1016/j.jglr.2017.10.004

Khodzher T.V., Domysheva V.M., Sorokovikova L.M. et al. 2017. Current chemical composition of Lake Baikal water. Inland Waters 7: 250-258. DOI: 10.1080/20442041.2017.1329982

Kostoski G., Albrecht C., Trajanovski S. et al. 2010. A freshwater biodiversity hotspot under pressure - assessing threats and identifying conservation needs for ancient Lake Ohrid. Biogeosciences 7: 3999-4015. DOI: 10.5194/bg-73999-2010

Kozhov M.M. 1963. Lake Baikal and its life. Dr. W. Junk, Publ. The Hague.

Kozhov M.M., Izhboldina L.A., Kaplina G.S. et al. 1969. Benthos of the south-east coast of Lake Baikal. In: Biological productivity of Siberian water bodies. Moscow: Nauka, pp. 29-37. (in Russian)

Kravtsova L.S., Timoshkin O.A., Rozhkova N.A. et al. 2009. Seasonal variations of macrozoobenthos as a basis for predicting ecological processes in the coastal zone of Lake Baikal. In: Timoshkin O.A. (Ed.), Index of animal species inhabiting Lake Baikal and its catchment area II (1). Novosibirsk, pp. 827-842. (in Russian)

Kravtsova L.S., Izhboldina L.A., Khanaev I.V. et al. 2012. Disturbances of the vertical zoning of greenalgae in the coastal part of the Listvennichnyi gulf of Lake Baikal. Doklady Biological Sciences 447: 227-229. DOI: 10.1134/ S0012496612060026 (in Russian)

Kravtsova L.S., Izhboldina L.A., Khanaev I.V. et al. 2014. Nearshore benthic blooms filamentous green algae in Lake Baikal. Journal of Great Lakes Research 40: 441-448. DOI: 10.1016/j.jglr.2014.02.019

Kulikova N.N., Maksimova N.V., Suturin A.N. et al. 2007. Biogeochemical characteristics of dominant gastropod species from the stony littoral of Southern Baikal. Geochemistry International 45: 478-489.

Kulikova N.N., Paradina L.F., Suturin A.N. et al. 2008a. Trace element composition of all-the-year-round vegetating macro-algae on the stony littoral of Lake Baikal (Russia). Algologiya 18: 244-255. (in Russian)

Kulikova N.N., Suturin A.N., Boiko S.M. et al. 2008b. Original data on the diversity, ecology, and chemical composition of aquatic and semiaquatic Lichens (Lichenes) of the stony littoral of Lake Baikal. Contemporary Problems of Ecology 1: 316-321.

Kulikova N.N., Rozhkova N.A., Timoshkin O.A. et al. 2009a. Distribution peculiarities of encrusting sponges (Lubomirskiidae family) in the littoral zone of Lake Baikal depending on the different rock types of the bottom. In: Timoshkin O.A. (Ed.), Index of animal species inhabiting Lake Baikal and its catchment area II (1). Novosibirsk: Nauka, pp. 913-916. (in Russian)

Kulikova N.N., Suturin A.N., Boiko S.M. et al. 2009b. Water lichens in biogeochemical processes in the stony littoral of Lake Baikal. Inland Water Biology 2: 144-148. DOI: 10.1134/ S1995082909020060

Kulikova N.N., Suturin A.N., Saibatalova E.V. et al. 2011. Geologic and biogeochemical role of crustose aquatic lichens in Lake Baikal. Geochemistry International 49: 66-75. DOI: 10.1134/S0016702910111023

Kulikova N.N., Suturin A.N., Saibatalova E.V. et al. 2012. Biogeochemistry of the shore zone of Bol'shye Koty bay (Southern Baikal). Izvestiya Irkutskogo Gosudarstvennogo Universiteta [The Bulletin of Irkutsk State University] 5: 75-87. (in Russian)
Kulikova N.N., Saibatalova E.V., Boiko S.M. et al. 2013. Biogeochemistry of encrusting sponges of the Family Lubomirskiidae in Southern Lake Baikal. Geochemistry International 51: 326-337. DOI: 10.1134/S0016702913040046

Kulikova N.N., Mekhanikova I.V., Chebykin E.P. et al. 2017. Chemical element composition and amphipod concentration function in Baikal littoral zone. Water Resources 44: 497-511. DOI: 10.1134/S0097807817030125

Kulikova N.N., Volkova E.A., Bondarenko N.A. et al. 2018. Elemental composition and biogeochemical functions of alga Ulothrix zonata (F. Weber et Mohr) in the coastal zone of South Baikal. Water Resources 45: 656-669. DOI: 10.1134/ S0097807818060106

Moore M.V., Hampton S.E., Izmest'eva L.R. et al. 2009. Climate change and the world's "Sacred Sea" - Lake Baikal, Siberia. Bioscience 59: 405-417. DOI: 10.1525/ bio.2009.59.5.8

Obolkina L.A., Bondarenko N.A., Doroschenko L.Ph. et al. 2000. On the discovery of cryophilic community in Lake Baikal. Doklady Akademii Nauk 371: 815-817. (in Russian)

Obolkina L.A. 2003. Plankton Ciliophorans of Lake Baikal: ecology and taxonomy. Cand. Sc. Dissertation, Irkutsk State University, Irkutsk, Russia. (in Russian)

Parfenova V.V., Malnik V.V., Boiko S.M. et al. 2008. Hydrobiont communities, developing at the interface water-rocks in Lake Baikal. Russian Journal of Ecology 3: 211-216. (in Russian)

Persistent organic pollutants (POP) on Baikal natural territory. 2017. Scientific report Obninsk, 38 pp. [www.rpatyphoon.ru/upload/medialibrary/239/POPs_bpt_2015-2016_2. pdf] (in Russian)

Rozhkova N.A., Maximova N.V., Weinberg I.V. et al. 2018. Macrozoobenthos of the stony littoral of the western coast of South Baikal: current state and multiyear dynamics. In: International Conference "Freshwater Ecosystems - Key Problems", pp. 284-285.

Samsonov D.P., Kochetkov A.I., Pasynkova E.M. et al. 2017. Levels of persistent organic pollutants in the components of Lake Baikal unique ecosystem. Meteorologiya i Gidrologiya [Meteorology and Hydrology] 5: 105-115. (in Russian)

Sideleva V.G., Nagorny V.K. 1985. Peculiarities of reproduction and fertility of Baikal sculpins (Cottoidei). Zoologicheskii Zhurnal [Russian Journal of Zoology] 64: 384-392. (in Russian)

Suturin A.N., Timoshkin O.A., Paradina L.F. et al. 2003. Biogeochemical processes on the stony littoral - unlimited element and nutrient source for Baikal ecosystem. Berliner Palaeobiologische Abhandlungen 4: 129-139.

Taliev D.N. 1955. Cottidei of Lake Baikal. Moscow-Leningrad: Nauka. (in Russian)

Timoshkin O.A., Bondarenko N.A., Obolkina L.A. et al. 2000. Pelagic and benthic communities of Lake Baikal: correlation of the cycles in their development? In: Third International Wereshchagin Baikal Conference, pp. 234-235.

Timoshkin O.A. 2001. Lake Baikal: biodiversity of fauna, the problems of its "immiscibility" and origin, ecology and "exotic" communities. In: Timoshkin O.A. (Ed.), Index of animal species inhabiting Lake Baikal and its catchment area I (1). Novosibirsk: Nauka, pp. 74-113. (in Russian and English)

Timoshkin O.A., Suturin A.N., Maximova N.V. et al. 2003. Rock preferences and microdistribution peculiarities of Porifera and Gastropoda in the shallow littoral zone of Lake Baikal (East Siberia) as evidenced by underwater macrophotograph analysis. Berliner Palaeobiologische Abhandlungen 4: 193-200.

Timoshkin O.A., Coulter G., Wada E. et al. 2005. Is the concept of a universal monitoring system realistic? Landscape-ecological investigations on Lake Baikal (East Siberia) 
as a possible model. Internationale Vereinigung für Theoretische und Angewandte Limnologie: 29: 315-320. DOI: 10.1080/03680770.2005.11902021

Timoshkin O.A., Suturin A.N., Wada E. et al. 2009. Is it possible to elaborate a universal scheme of ecosystem monitoring? Landscape-ecological research on Lake Baikal as a possible positive answer. In: Timoshkin O.A. (Ed.), Index of animal species inhabiting Lake Baikal and its catchment area II (1). Novosibirsk: Nauka, pp. 708-726. (in Russian)

Timoshkin O.A., Suturin A.N., Bondarenko N.A. et al. 2011. Biology of the coastal zone of Lake Baikal. 1. Splash zone: first results of interdisciplinary investigations and its role for the lake ecosystem monitoring. Izvestiya Irkutskogo Gosudarstvennogo Universiteta [The Bulletin of Irkutsk State University] 4: 75-110. (in Russian)

Timoshkin O.A., Suturin A.N., Bondarenko N.A. et al. 2012a. Introduction into biology of the coastal zone of Lake Baikal. 1. Splash zone: first results of interdisciplinary investigations and its role for the lake ecosystem monitoring. Izvestiya Irkutskogo Gosudarstvennogo Universiteta [The Bulletin of Irkutsk State University] 5: 33-46.

Timoshkin O.A., Vishnyakov V.S., Volkova E.A. et al. 2012b. Biology of the coastal zone of Lake Baikal. 2. Accumulated material on the lake shore (splash zone): classification, seasonal dynamics. Izvestiya Irkutskogo Gosudarstvennogo Universiteta [The Bulletin of Irkutsk State University] 5: 4091. (in Russian)

Timoshkin O.A., Tomberg I.V., Kulikova N.N. et al. 2012c. Biology of the coastal zone of Lake Baikal. 3. Seasonal dynamics of the infauna of the onshore accumulated material, hydrochemical and microbiological analyses of interstitial water in the splash zone. Izvestiya Irkutskogo Gosudarstvennogo Universiteta [The Bulletin of Irkutsk State University] 5: 92-110. (in Russian)

Timoshkin O.A., Malnik V.V., Sakirko M.V. et al. 2015. Ecological crisis on Lake Baikal: Diagnosed by Scientists. Science First Hand 2: 25-41.

Timoshkin O.A., Bondarenko N.A., Volkova E.A. et al. 2015. Mass development of green filamentous algae of the genera Spirogyra and Stigeoclonium (Chlorophyta) in the littoral zone of the Southern Part of Lake Baikal. Hydrobiological Journal 51: 13-23. DOI: 10.1615/HydrobJ.v51.i1.20

Timoshkin O.A., Samsonov D.P., Yamamuro M. et al.
2016. Rapid ecological change in the coastal zone of Lake Baikal (East Siberia): Is the site of the world's greatest freshwater biodiversity in danger? Journal of Great Lakes Research 42: 487-497. DOI: 10.1016/j.jglr.2016.02.011

Timoshkin O.A., Moore M.V., Kulikova N.N. et al. 2018. Groundwater contamination by sewage causes benthic algal outbreaks in the littoral zone of Lake Baikal (East Siberia). Journal of Great Lakes Research 44: 230-244. DOI: 10.1016/j. jglr.2018.01.008

Timoshkin O.A. 2018. The oldest lake of the planet (Lake Baikal) experiences rapid ecological changes in the coastal zone. SIL News 72: 9-12.

Tomberg I.V., Sakirko M.V., Domysheva V.M. et al. 2012. First data on the chemical composition of interstitial waters in the splash zone of Lake Baikal. Izvestiya Irkutskogo gosudarstvennogo universiteta [The Bulletin of Irkutsk State University] 5: 64-74. (in Russian)

Volkova E.A., Tomberg I.V., Popova O.V. et al. 2012. Influence of the green algae Ulothrix zonata (Web. et Mohr) Kuetz on diurnal and seasonal hydro-chemical variations in the near-shore waters of Lake Baikal. Izvestiya Irkutskogo gosudarstvennogo universiteta [The Bulletin of Irkutsk State University] 5: 160-166. (in Russian)

Vadeboncoeur Y., McIntyre P.B., Vander Zanden J. 2011. Borders of biodiversity: life at the Edge of the World's large lakes. Bioscience 61: 526-537. DOI: 10.1525/bio.2011.61.7.7

von Rintelen T., von Rintelen K., Glaubrecht M. et al. 2012. Aquatic biodiversity hotspots in Wallacea: the species flocks in the ancient lakes of Sulawesi, Indonesia. In: Gower D.J. et al. (Eds.), Biotic Evolution and Environmental Change in Southeast Asia. Cambridge, pp. 290-315.

Volkova E.A., Bondarenko N.A., Timoshkin O.A. 2018. Morphotaxonomy, distribution and abundance of Spirogyra (Zygnematophyceae, Charophyta) in Lake Baikal, East Siberia. Phycologia 57: 298-308. DOI: 10.2216/17-69.1

Yamamuro M., Kayanne H., Yamano H. 2003. $\delta 15 \mathrm{~N}$ of seagrass leaves for monitoring anthropogenic nutrient increases in coral reef ecosystems. Marine Pollution Bulletin 46: 452-458. DOI: 10.1016/S0025-326X(02)00463-0

Zohary T., Gasith A. 2014. The littoral zone. Aquatic Ecology Series 6: 517-532. DOI 10.1007/978-94-017-89448_29 